\title{
Az ipar 4.0 komplexitása - I.
}

Kétrészes tanulmányunk célja, hogy egy összetettebb megközelítéssel meghaladjuk a negyedik ipari forradalomról szóló szokásos elemzéseket. Mindezt rendszerszemléletben tesszük, azaz az ipar 4.0 és a digitális gazdaság kérdését a társadalmi-gazdasági rendszer szerkezetével összevetve vizsgáljuk. Azokra a területekre és összefüggésekre koncentrálunk, ahol már most érzékelhetők a változások. Az I. rész áttekinti az ipar 4.0 és a digitális gazdaság mibenlétét, vázolja az európai ipar jelenlegi helyzetét, rámutat a főbb tendenciák mozgató mechanizmusaira. Bemutatjuk, hogy megkerülhetetlen az ipar 4.0 komplexitásának mélyebb feltárása, amire a II. részben teszünk kísérletet. Bizonyos átváltások, szinergiahatások és nem szándékolt következmények ugyanis arra intenek, hogy az érzékelhető változások mellett változtatásokra is szükség van. Megfogalmazzuk az intelligens gazdasági kormányzás néhány elvi minimumkritériumát, amivel az ipar 4.0 és a digitális gazdaság kibontakozása fenntarthatóvá tehető.*

Journal of Economic Literature (JEL) kód: L5, L6, O25, O4, 03.

Az ipar 4.0 fogalmát egyesek úgy emlegetik, mint gőzerővel digitalizálódó világunk, vagyis napjaink kapitalizmusának új fejezetét. A megközelítés szerint a történelmi szükségszerüség diktálja, hogy újragondoljuk a célzott iparpolitika lehetőségét, mi több, ismét célzott és felelősségteljes szakpolitikai ággá formáljuk ahhoz, hogy határozottabban előmozdíthassuk a gazdasági növekedést és fejlődést.

Csakhogy az iparpolitika meglehetősen idejétmúltnak számít. Ennek két, empirikusan jól dokumentált közgazdasági oka van. Először, a célzott iparpolitika az állam mindenható voltának hamis illúzióját keltheti azáltal, hogy szelektál, és kiemeli azokat az iparágakat (technológiákat s adott esetben konkrét vállalatokat), amelyeket jelenleg és a jövőben is sikeresnek ítél. Másodszor, a szelekciós mechanizmuson keresztül - bizonyos lobbicsoportok megerősödnek - az állam foglyul

* A tanulmány a VEKOP-15-2016-00001 azonosítószámú, A jó kormányzást megalapozó közszolgálatfejlesztés elnevezésű kiemelt projekt részeként működtetett Ludovika Kiemelt Kutatóműhely keretében a Nemzeti Közszolgálati Egyetem felkérésére készült.

Kovács Olivér az ICEG European Center tudományos munkatársa (web: http://oliverkovacs.com). A kézirat első változata 2017. május 9-én érkezett szerkesztőségünkbe.

DOI: http://dx.doi.org/10.18414/KSZ.2017.7-8.823 
ejthetővé válik a rendszerben. Ily módon tehát az iparpolitika torzíthatja a versenyt, illetve a megfelelő kormányzástól eltérítő - azaz részrehajló és nem hatékony - szakpolitikához vezethet.

Az emberiség azonban- így a fejlett országok is - olyan komplex, országhatárokon átívelö kihívások láncolatával áll szemben, hogy szükségszerü újragondolni az iparpolitika finomhangolhatóságának kérdését annak érdekében, hogy a termelési és fogyasztási ökoszisztémát minél jobban közelítsük a fenntartható fejlödés céljaihoz. ${ }^{1}$ Kollektív cselekvésre van szükség megannyi területen, így a klímaváltozás lefékezése terén is. ${ }^{2} \mathrm{Az}$ iparpolitikai megfontolás itt is megjelenhet, hiszen bizonyos fokú szelektivitásra van szükség ahhoz, hogy a „piszkos” technológiákat minél könnyebben felválthassák a „tiszták”. ${ }^{3}$ A pénzügyi szféra és a reálgazdaság megbomlott harmóniájának visszaállítása is építhet iparpolitikai megfontolásokra (például a fenntartható fejlődést és versenyképességet szolgáló, exportképes szektorok támogatása, innovációs környezetük javítása a hosszú távú termelékenységi stagnálás megtöréséhez); a feltörekvő piacokon egyre gyakrabban lehet találkozni különböző, növekedésorientált ágazati szakpolitikákkal, amelyeket a versenytársaknak figyelembe kell venni.

Hatékonyabb szakpolitika pedig csak a tendenciák jobb megértésével alakítható ki. A tendenciák egyre világosabbak, fordulópontokat jelentö technológiai és nem technológiai innovációk születnek, amelyek további kiaknázandó lehetőségeket s ezáltal transzformatív eröt rejtenek magukban. ${ }^{4}$

Kétrészes tanulmányunkban áttekintjük az ipar 4.0 fogalmával kapcsolatos jelenlegi véleményeket. Nem kívánunk a jövőkutatás mezsgyéjére lépni, sokkal inkább azokra a területekre koncentrálunk, ahol már most érzékelhetők a változások. Módszerünk a szintetizáló jellegű irodalomfeldolgozás és a kritikai elemzés. Az iparfejlödéssel összefüggő legfontosabb trendeket nyilvánosan hozzáférhető adatbázisok segítségével vázoljuk. Az utóbbi során elsősorban - és az adatok elérhetősége függvényében - a releváns európai uniós országokra (Ausztria, Franciaország, Magyarország, Németország és az Egyesült Királyság), vala mint a legfontosabb versenytársakra (Egyesült Államok, Kína, Japán, Dél-Korea) helyezzük a hangsúlyt.

\footnotetext{
${ }^{1}$ Az iparpolitika finomhangolhatóságáról lásd még Aiginger [2015].

${ }^{2}$ Az egyik legújabb állomás a kollektív cselekvés terén - a 2015-ben elfogadott párizsi éghajlatvédelmi egyezményen túl - az újonnan létrejövő környezetvédelmi bíróságok rendszere a világ több mint 50 országában.

${ }^{3}$ Például „tiszta” iparágak fejlesztése, energiahatékonyságot növelő megoldásokba történő közösségi és főleg magánberuházások fellendítése mind a tiszta, mind a szennyező technológiai szektorokban stb. (lásd Aghion és szerzőtársai [2011], Walz [2015]).

${ }^{4}$ A Világgazdasági Fórum alapítója és elnöke, Klaus Schwab szerint többek közt ilyen lehet a testbe épített technológiai eszközök fejlődése [agyba építhető mikrocsip előre jelezheti és meg is akadályozhatja az epilepsziás rohamot (https://www.humanbrainproject.eu), az internetre kapcsolt szemüvegek megjelenése] a dolgok internete (Internet of Things, IoT), az okos városok, a vezető nélküli autó továbbfejlesztése, a mesterséges intelligencia megjelenése, a robotika fejlődése, a 3D nyomtatás elérhetősége (Schwab [2016] 25-27. o.) De a jövő iparágainak számbavételekor is ezeket említik (például Ross [2016]).
} 


\section{Az ipar 4.0 szintetizált értelmezése}

Az ipar 4.0 fogalmát Németországban kezdték használni (Acatech [2013], [2015]), utalva a mindent átható digitalizáció és elektronikus összeköttetés nyújtotta azon lehetőségekre, amelyek forradalmian átrendezhetik és újabb minőségi szintre emelhetik a termelési módozatokat. A termelékenység robbanásszerü javulását remélik tőle, ami létfontosságú az országok versenyképessége, a fenntartható gazdasági növekedés szempontjából. Az ipar 4.0 kifejezés arra a technológiai forradalomra utal, amely az 1970-es évektől a mikroprocesszorok feltalálásával indult, s belőle bontakozott ki az információs és kommunikációs technológia (IKT), az automatizálás lehetősége. Ezek lehetővé tették, hogy ma már információs forradalomról, tudásgazdaságról, „új gazdaság” kialakulásáról beszélhessünk (Kovács [2015a]). Érdemes hangsúlyozni, hogy az ipar 4.0 az „új gazdaság” kereteit még nem feltétlen feszíti széjjel: az információs és kommunikációs technológia mindent átható és a korábbiaknál szélesebb felhasználásáról van szó az üzleti, kormányzati és civil szférában egyaránt - amikor a szenzoros technológiáról, a dolgok internetéről (Internet of Things, IoT), a nagyobb mennyiségü és sokszor valós idejü adatok (Big Data) ${ }^{5}$ kinyerhetőségéről és elemezhetőségéről beszélnek.

Az ipar 4.0 szintetizáló jellegű definíciója - figyelembe véve az eredeti német fogalmat (Acatech [2013], [2015]), továbbá a nemzetközi szervezetek (OECD [2016] 3. o.), valamint az Európai Unió narratíváit (EP [2016] 20. o.) - alapvetően a következő: a dolgok és szolgáltatások internetére (IoT) építő új gyártási filozófia és müködési mód, amely során okos gyárak (smart factories) jönnek létre azáltal, hogy az erőforrásokat, a gépeket és még a logisztikai rendszereket is online integrált rendszerré, egyfajta kiberfizikai rendszerré kötik össze. Ily módon pedig független és optimalizáló helyi termelési folyamatokat hozunk létre. A helyi azt jelenti, hogy különböző technológiák révén maguk az egyes gyártóegységek is (például a szenzorok) okosakká válnak, és központi helyett helyi - azaz decentralizált - ellenőrzés valósul meg. A nemzetközi szakirodalom kilenc technológia egymásra ható fejlődését sorolja az ipar 4.0 kibontakozásával kapcsolatban: 1. Big Data-analitika, 2. autonóm gépek, robotok, 3. szimulációk, 4. horizontális és vertikális rendszerek integrálása, 5. a dolgok ipari internete, 6 . kiberbiztonság, 7. felhötechnológia; 8 . additív gyártás és 9. kiterjesztett valóság (lásd például BCG [2015]).

A következőkben felmérjük, hogyan válik versenytényezővé az energia- és eröforrás-hatékony müködés, milyen következményekkel számolhatunk, figyelembe véve a világgazdasági hátteret is.

\footnotetext{
${ }^{5}$ Az emberi civilizáció kezdete óta egyes becslések szerint 5 exabájtnyi adat jött létre 2003-ig. Napjainkban tizennyolc naponta hozunk létre ennyi adatot (Einav-Levin [2014]). Például percenként közel 2,5 millió tartalmat osztanak meg a Facebookon, 72 órányi videótartalom kerül fel a YouTube-ra (https://aci.info/2014/07/12/the-data-explosion-in-2014-minute-by-minute-infographic).
} 


\section{Az ipar 4.0 várható hatásai}

A várakozások szerint az ipar 4.0 forradalmian átalakítja munka- és életkörülményeinket: számos területen javul a hatékonyság, ami egyszersmind közelebb visz a gazdaságok „kizöldítéséhez”, ${ }^{6}$ másrészt közvetlen és áttételes hatásokon keresztül segít megfordítani a fejlett világban évtizedek óta kimutatott termelékenyégnövekedés romló tendenciáját. A mértékadó nemzetközi szervezetek előrejelzései egyre lejjebb teszik az elérhető potenciális gazdasági növekedés rátáját. ${ }^{7}$ A romló termelékenység megbontja a gazdasági növekedés szövetét, hiszen ilyen körülmények között az államháztartás fenntarthatósága szigorító intézkedésekért és fájdalmasabb (a vagyoni és jövedelemegyenlötlenséget súlyosbító) strukturális reformokért kiált, mert a jóléti szolgáltatások, így a demográfiai változások finanszírozása még problémásabbá válik, mivel sérül az üzleti szektor kockázatvállalási hajlandósága és kreatív munkaerőre történő építési lehetősége, ami az alacsony termelékenységhez vezet vissza. ${ }^{8}$

Alapvető dilemma, hogy vajon miért tapasztalható a hosszú távú stagnálás a fejlett világban, ${ }^{9}$ azaz egyre kisebbek a termelékenységi javulásokhoz vezető innovációs teljesítmények, amikor ezzel párhuzamosan soha nem látott digitalizációt élünk meg (Digital Economy, Platform Economy). A kérdés azért fontos, mert ha igazolódna, hogy csak szerény termelékenységi hozzájárulást remélhetünk a digitalizációtól, akkor alapvetően megváltozhatnak az üzleti beruházási döntések, a piaci viselkedés. ${ }^{10}$ Ha pedig nagyobb hatás várható, mint amivel a szakma számol, akkor érdemes jobban felkészülni a kihívásokra és megvizsgálni, hogy mi a teendője a szakpolitikának és a szabályozásnak. ${ }^{11}$

${ }^{6}$ Okos irányítás mellett az egyes berendezések és gépek készenléti üzemmódba kapcsolnak üresjáratok alatt, így nő az energiahatékonyság. Erről lásd Acatech [2013]. De a Big Data a precíziós mezőgazdaságban is óriási szerepet játszik, ehhez lásd például Bőgel [2015].

${ }^{7}$ Van Ark és szerzőtársai [2016] például 2020 után fokozatos lassulást vetít előre. Az IMF [2016] pedig folyamatosan írja felül korábbi elörejelzéseit, és 2021-re is azt jósolja, hogy az euróövezet növekedési rátája még mindig 15 százalékkal a 2008-as válságot megelőző 1999-2007-es időszak növekedési rátája alatt lesz.

${ }^{8}$ Stagnálnak a bérek - az Egyesült Államokban a medián jövedelem 1979 és 2013 között csak 0,32 százalékkal nőtt, míg az egy före jutó GDP 1,6 százalékkal (Nolan és szerzőtársai [2016]) -, ami hoszszabb távon a tanulni vágyó és motivált munkaerő foglalkoztatásának a rovására megy, így pedig az innovációs aktivitás további visszafogásához vezethet.

${ }^{9}$ Lásd Cowen [2011], Gordon [2012], Teulings-Baldwin [2014], Bergeaud és szerzötársai [2015], IMF [2015], OECD [2015a], Blanchard [2016] vagy Halmai [2014]. Az euróövezet teljes tényezőtermelékenységének növekedése például 2000 és 2015 között gyakorlatilag majdnem leállt (évente átlagosan mindössze 0,2 százalékot javult), az Egyesült Államokban is csak 0,4 százalék volt (McQuinn-Whelan [2015]).

${ }^{10} \mathrm{Ez}$ a forgatókönyv azért reális, mert az infokommunikációs eszközök és digitális szolgáltatások árának csökkenése nem feltétlen vezet fokozott innovációhoz a későbbiekben. Mi több, a Big Data alapú üzleti analitikai megoldások (sőt az innovatív, kreatív munkavállalók kiválasztásával foglalkozó „people analytics", lásd Isson-Harriott [2016]) romboló hatásúak (disruptive) lehetnek az üzleti modellekre, a versenytársakra, így összességében egyáltalán nem garantált fenntarthatóan a magasabb termelékenység.

${ }^{11}$ Utóbbi azért is lehetséges, mert csökken a digitalizáció kezdeti magas beruházási költsége, hiszen a felhőalapú megoldások révén eltolódik a hangsúly a digitális állóeszközökbe történő költségesebb beruházások (hardver, szoftver, infokommunikációs eszközök) felől a megvásárolható és olcsóbb digitális szolgáltatások felé. 
Az összefüggések bonyolult láncolatának feltárása a hosszú távú stagnálás jobb megértéséhez és az ipar 4.0 nyújtotta lehetőségek pontosabb beazonosításához vezethet. Gondoljunk csak az alacsony gazdasági növekedés-beszükült szakpolitikai mozgástér kapcsolatra, ${ }^{12}$ illetve az alacsony növekedés-növekvő vagyoni-jövedelmi különbségek összefüggésére, amelyek számos kérdést vetnek fel, és óvatosságra intenek az elörejelzések tekintetében. Természetesen az is igaz, hogy amikor előrejelzéseket készítenek, a mérhetőség terén tetten érhető problémáknak nagy jelentőségük van (például a mai innovációk - föleg a szolgáltatási szektor innovációi - inkább minőségi, a GDP-ben nem számszerűsíthető kategóriákban mutatnak javulást, így a termelékenységi rátában sem jelennek meg). ${ }^{13}$

A globális lassulás egymással összekapcsolódó, egymásra nem lineárisan ható és inkább egymást erősítő csatornákon zajlik. A legjelentősebbek a következők:

1. a 2008-as pénzügyi és reálgazdasági válság utóélete - alacsony infláció, alacsony növekedés időszaka;

2. a feltörekvő piacok lassuló felzárkózása, érzékelhető strukturális alkalmazkodása a fenntarthatóbb, lassabb növekedéshez;

3. a fejlett világban, föleg Európában még nyomatékosabban jelentkezik a szabályozás bonyolultsága és a gyengülő verseny negatív hatása recessziós időszakban;

4. a technológia és innováció már a válság előtt sem növelte a korábbi mértékben a vállalati termelékenységet;

5. a reálgazdaság és a pénzügyi szféra közötti súlyponteltolódás a pénzügyi szektor javára: ez utóbbinak klasszikus közvetítőrendszeri értékteremtő jellege jelentősen megkopott, ami viszont elősegítette, hogy a fő befektetési célpontok elsődlegesen pénzügyi befektetések legyenek, így fokozva a buborékok, a rendszerszintü kockázatok kialakulásának veszélyét, az alacsony vállalati beruházási rátát, az alacsony innovációs hajlamot; ${ }^{14}$

6. nőtt az egyenlőtlenség, ami aláássa a társadalmi bizalmat, ami negatív ördögi spirál formájában visszacsatol a lassuló gazdasági dinamizmushoz.

\footnotetext{
${ }^{12}$ Említésre méltó forrása a termelékenységromlásnak az a tény, hogy az ENSZ Population Divisions adatbázisa szerint a fejlett gazdaságokban a munkaképes korú népesség növekedési rátája egyre kisebb. Ebből a szempontból Magyarország Japán után az egyik legrosszabb helyzetben van, hiszen 2005 és 2015 között Japánban 9 százalékkal, Magyarországon pedig 4 százalékkal esett vissza a munkaképes korú lakosság száma. Az elörevetítések pedig igen borúsak. Másrészt az is igaz, hogy a fejlett országok 200 éves tapasztalata szerint az alacsony növekedésü periódusok mindig az adósságráta emelkedésével jártak (Mauro-Zilinsky [2016]). S ez a helyzet ma is: a világgazdasági GDP 225 százalékát tette ki a globális adósság 2016-ban, ami rekord magas (IMF [2016]). Vagyis szűkül a költségvetési mozgástér, kevesebb a produktív beruházásokra fordítható tőke.

${ }^{13}$ Bár a mérési hibák jelen vannak, a termelékenység növekedésében megfigyelhető gyengülés és romlás valóban létezik. Az Egyesült Államok esetében lásd Byrne és szerzőtársai [2016] elemzését.

${ }^{14}$ Ez tetten érhető a túlzott mértékű hitelfelvételben (Berend [2013] 108-112. o.), abban, hogy a belső pénzügyi kitettség a derivatív piacokon túlzott méreteket öltött (ESBR [2016]). A legfelső jövedelmi osztály (felső 1 százalék) jövedelme az elmúlt 30-35 év során 200 százalékkal nőtt, míg a legalacsonyabb 20-25 százalék jövedelme szinte stagnált. Turner [2015] provokatív kötete bemutatja, hogy a felsőbb réteg megtakarításait a pénzügyi rendszer igyekezett kihelyezni, így nőtt széles rétegekben az eladósodás. Vagyis nőtt a jövedelemegyenlőtlenség.
} 
A várakozásoknak központi szerepük van: a pénzügyi szféra lélektanilag vezényelt természetét ez is megalapozza, nem véletlen, hogy a dot.com léggömb felfúvódása is azokon a várakozásokon nyugodott, hogy az infokommunikációs for radalommal elöálló technológiai eszközök árcsökkenése javítja a termelékenységet a használatukra építö többi szektorban is. Hoon-Phelps [2006] szerint ez a várakozás hamis (később Phelps [2013] 225. o. ismét kitért a kérdésre).

Az eddigi vizsgálatok egyelöre azt emelik ki, hogy az infokommunikációs technológiára építő ipar 4.0 a digitális gazdaság terén egyelőre installációs szakaszban vagyunk, pozitív hatás csak fokozatosan várható (Byrne-Corrado [2017], OECD [2016], Van Ark és szerzőtársai [2016]). Teljes kiaknázásához szükség van tudástőkeés szervezetfejlesztésre. ${ }^{15}$ A teljes kibontakozáshoz önmagában az ipar 4.0 technológiáinak mikorszintü átvétele nem elégséges: az értékteremtő diffúzió megvalósulásához a kiegészítő emberi tőkébe - a képesség- és készségfejlesztésbe, a hallgatólagos tudásbázis kiaknázásába - is invesztálni kell, és finomítani kell az egész innovációs ökoszisztéma intézményi keretrendszerét. Az ipar 4.0-tól azt várják, hogy több területen szinergikusan hasson (Monostori [2017]). ${ }^{16}$

Összességében az ipar 4.0 legalább három fronton eredményez változásokat és kényszerít ki változtatásokat a társadalmi-gazdasági innovációs ökoszisztéma szereplőitől: az üzleti/vállalati szektorban, a kormányzati és szabályozói szektorban, valamint a lakosság körében, a civil szférában.

Üzleti, vállalati szektor. Az ipar 4.0, a digitális gazdaság akár radikálisan is megváltoztathatja a fogyasztók várakozásait, a termékeket és a szolgáltatásokat továbbfejlesztheti, új üzleti modelleket kényszeríthet ki. Nemcsak hogy hatékonyabbá válik az üzletvitel, ${ }^{17}$ nemcsak hogy megváltozik a különböző szektorok jelentősége, de mindezzel párhuzamosan a munkaerőpiac is átalakul, növekszik az önfoglalkoztatás, csökken a tartós foglalkoztatás, és intenzívebbé válik a határozott idejü, átmeneti foglalkoztatás. A kínálati oldalon egyre több iparági szereplő észleli az újabb és újabb technológiák elérhetőségét, amelyek a felhasználói/fogyasztói igények kielégítésének új minőségét és módját teszik lehetővé. Az ipar 4.0 technológiái és az azokra építő szolgáltatások az értékláncot is átformálják. Közben a piacok megtámadhatósága is felerösödött azáltal, ${ }^{18}$

${ }^{15}$ Ezt erősíti Kretschmer [2012] vagy van Welsum és szerzőtársai [2012] áttekintő munkája is. 1891 és 2012 között a fejlett országokban két termelékenységi felívelés volt megfigyelhető. Az első az elektromos energia, a belső égésű motorok megjelenése után, míg a második - ami már kisebb mértékü, és rövidebb ideig is tartott - az infokommunikációs technológia megjelenése után. Az 1980-as évek óta azonban erőteljesebben megkérdőjelezhető az infokommunikációs technológia termelékenységet javító (mérhető) hatása (lásd Bergeaud és szerzőtársai [2014] vagy Kortum-Pillai [2015] írását a Mooretörvény meggyengüléséről).

${ }^{16}$ Nem véletlen, hogy életre hívták az OECD-n belül a termelékenység globális fórumát (Global Forum on Productivity), amely egyebek mellett azt igyekszik igazolni, hogy az általános innovációs teljesítmény gyengülésében (így pedig a romló termelékenységben) lényeges szerepet játszik, hogy az intézmények (vagy azok hiánya) gátolják a diffúziót.

${ }^{17}$ A világhálón és a Big Datán alapuló üzleti analitika hatékony felhasználása éves szinten körülbelül 425 milliárd eurós költségmegtakarítást jelenthet 2020-ig a 100 legnagyobb uniós vállalat életében $(E C[2016 a])$.

${ }^{18}$ A digitalizáció hatására fokozódik bizonyos piacok megtámadhatósága (contestability), hiszen ár-összehasonlító platformok üzemelnek, ezáltal növekszik az átláthatóság, s csillapodhat a mono- 
hogy a kutatás-fejlesztés és innováció, a marketing, az értékesítés és disztribúció új formáit jelentő digitális platformokhoz történő hozzáférés s a kimüvelt tehetségek elérése is globálissá vált (Kovács [2016]). Tartós versenyelőny az értékteremtést elömozdító folyamatos fizikai-digitális innovációtól remélhető. A keresleti oldalon pedig az várható, hogy még intenzívebben jelentkezik a fogyasztó bevonása (co-creation, co-design). Továbbá bővül az új típusú fogyasztási modellek köre is (technológiai platformokon alapuló, megosztásra épülö szolgáltatások).

A változások spektrumát a vállalatvezetőknek nyomon kell követniük, és alkalmazkodniuk kell hozzá. Ez a pont lényegében átvezet a kormányzati szektorhoz, hisz nyilvánvaló, hogy számít a méret és az erőforrás-ellátottság, tehát a nagyobb, erőforrásokban (tőke, tehetségek, netán adattudósok) bővelkedő vállalatok könnyebben, míg a kisebb és nem feltétlen innovatív, viszont fiatal cégek nehezebben képesek adaptálódni. Ez önmagában a nem teljesen neutrális szakpolitika irányába visz, ami egyébként teljesen bevett felfogás a regionális uniós fejlesztéspolitika területén. Ezért is bukkanhat fel az iparpolitikai fölfogás, amit már rég meghaladottnak hittünk a szolgáltató szektorok dominanciájára építő paradigmában. ${ }^{19}$ Bár az Egyesült Államokban ez a fajta felülről lefelé építő szakpolitikai gondolkodás nem igazán fér össze az aktuális gazdaságpolitikai nézetrendszerrel, náluk is megindult az ipar 4.0 (advanced manufacturing) előmozdíthatóságával foglalkozó diskurzus. ${ }^{20}$

Kormányzati, szabályozói szektor. Intézményi inercia van kódolva a modern társadalmi-gazdasági innovációs ökoszisztémába, s még az ipar 4.0 technológiái is olyanok, mint a korábbiak, abban a tekintetben legalábbis, hogy azok is megbontják a formális és informális intézmények szövetét, és változást és változtatást kényszerítenek ki, ugyanakkor ezek lefutása hosszabb időt vesz igénybe, mint ahogy a technológia fejlödik. Az igazságszolgáltatási rendszer, a szabályozói környezet lassabban alkalmazkodik. Hatásában bizonyosan tetten érhető majd az, hogy az ipar 4.0, illetve a digitalizáció az állampolgárok mélyebb és hatékonyabb bekapcsolódását teszi lehetővé a közügyekbe, sőt a kormányzásba. Ezzel párhuzamosan a lakosság ellenőrzésére bevethető kormányzási eszközök is fejlődnek. A választók, a lakosság (az ipar 4.0 és a digitális gazdaság fogyasztói és müködtetői) állami szektorral szembeni várakozásai is módosulnak. Az ipar 4.0 és a digitalizált gazdaság termékeinek és szolgáltatásainak minősége, elérhetösége növekszik, új norma alakul ki az állami szektor szolgáltatásaival kapcsolatosan is (hedonic adaptation). ${ }^{21}$ Ehhez az állami szektornak innovációkon keresztül fel kell nőnie,

polisztikus erőfölény. Viszont bennmaradni és fenntartható innovációkkal tovább müködni már nehezebb, hiszen rövidebb lesz a termékek és szolgáltatások életciklusa, könnyebb imitálni, kisebb tőkemennyiséget igényel egy új (például internetes) vállalkozás indítása (Blix [2015]).

${ }^{19}$ Az iparpolitika önmagában sejteti a nem neutrális jelleget. Vannak, akik másképp fogalmaznak: fejlesztéspolitikáról (Hausmann-Rodrik [2006]), misszióorientációs politikáról (Foray és szerzőtársai [2012]), okos specializációról (Foray [2014]) beszélnek.

${ }^{20}$ Még Obama elnök indított útjára két partnerségi megállapodást: Advanced Manufacturing Partnership I., II., illetve már létre is jött a National Network for Manufacturing Innovation (lásd még http://manufacturing.gov/ illetve http://ostaustria.org/bridges-magazine/item/8310-industry-4-0).

${ }^{21}$ A hedonikus adaptációt - vagy elégedettségi futópadot (satisfaction treadmill) - pszichológiai kutatások igazolták (lásd Kahneman [1999] vagy Kahneman és szerzötársai [2003]). Eme lélektani szempontot az állami szektor innovációival kapcsolatosan szintén tárgyaltuk már (lásd Kovács [2012]). 
szinergikus kapcsolatra kell törekednie. A digitalizáció miatt a decentralizáció új korszaka köszönthet be, amikor is az állami szektor és a magánszektor/civil szféra közti távolság lecsökkenthető még a központi kormányzat és a helyi szintek viszonylatában is. Így pedig tartósabb és sikeresebb együttmüködések jöhetnek létre. ${ }^{22}$

Lakossági, civil szektor. Előzetesen az várható, hogy a lakosság jobb minőségü szolgáltatásokat és kényelmi funkciókat vehet igénybe az élet megannyi területén (egészségügy, oktatás, élelmiszer-termelés és -fogyasztás, energiagazdálkodás stb.), ugyanakkor nem lehet eltagadni a negatív hatásokat sem. Ilyen lehet az, hogy várhatóan felerösödnek a félelmek a magánjellegű információk és adatok biztonságos kezelésével kapcsolatosan (amelyekre építenének például Big Data-analitikák során, nyilvánosságra hozott és elemezhető egészségügyi, pénzügyi adatok terén stb.). Vélhetően megváltoznak a tulajdoni formák és föleg a tulajdonlással kapcsolatos általános attitüd is (az olcsóbb bérleti konstrukciók vonzóbbakká válhatnak, mint a vétel és tulajdonlás). Bizonytalanságot hordoznak a munkaerőpiaci változások is (például az automatizálás, robotika okozta munkanélküliséget felszívják-e az új munkahelyek), ${ }^{23}$ nem beszélve az új technológiák és szolgáltatások lélektani befolyásoló erejéről. Ebből is következik, hogy az emberek életét az ipar 4.0 által megindított változások nagyban érintik, más típusú munkahelyek jönnek létre, amelyek a digitális készségek ${ }^{24}$ és programozási ismeretek magasabb szintjét igénylik, ${ }^{25}$ hogy eligazodjanak az egymáshoz konvergáló fizikai és digitális világban (ideértve a kormányzás-közigazgatás és polgárok közti kommunikációt is). ${ }^{26}$

\section{Az európai ipar helyzetéről - általános tendenciák}

Az ipari termelés továbbra is a fejlett gazdaságok meghatározó motorja. Az ipar az Európai Unió teljes bruttó hozzáadott értékének 20 százalékát adta 2005 és 2015 között - ezzel a legnagyobb hozzájárulónak számít. ${ }^{27}$ Az EU-ban közel 2,1 millió vállalat tevékenykedik az iparban, és közel 33 millió főt foglalkoztat. Az

${ }^{22}$ Decentralizáltabb struktúrában a közeli kapcsolat erősíti a bizalom infrastruktúráját, ezen keresztül pedig serkenti az innovációs együttmüködéseket. Kovács [2012] ezt is tárgyalja.

${ }^{23}$ A World Robotics Report 2016 becslései szerint 2017 és 2019 között az ipari robotok eladása átlagosan 13 százalékkal nő évente, és egyre komplexebb tevékenységekre is bevethetők lesznek (http:// worldrobotics.org).

${ }^{24} \mathrm{Az}$ automatizálás munkahelyekre gyakorolt összetett hatásával foglalkozó tanulmányok szerint természetesen a nem számítógépesített munkakörökben dolgozókat érintette eddig is a legnagyobb arányban az automatizálás okozta állásvesztés (Bessen [2016]). Azok, akik számítógépes munkakörökben dolgoztak, ha el is vesztették az állásukat, könnyebben találtak másutt.

${ }^{25}$ Egyre több adattudósra van szükség. Becslések szerint az Egyesült Királyságban a Big Data és IoT miatt körülbelül 182 ezer új állás jön létre 2020-ig, amelynek jelentős része adattudósoké (Hogan és szerzötársai [2016]).

${ }^{26}$ A választók, vagyis a civil szektor digitális politikai részvételéről és lehetőségeiről egyre több tanulmány szól, amelyek Big Data-módszertant kínálnak (Robles és szerzőtársai [2013], [2016]).

${ }^{27}$ Az Eurostat adatai alapján Ausztriában ez az érték 2005-ben 23,3 százalék, míg 2015-re 21,9 százalék, az Egyesült Királyságban 2005-ben 15,4 százalék, míg 2015-ben 13,3 százalék, az EU motorjának számító német gazdaságban 2005-ben 25,5 százalék, míg 2015-ben 25,9 százalék volt (összehasonlításképp Magyarországé is magasnak számít, 27,4 százalék volt 2015-ben). 
exporttevékenységek 80 százalékát az ipar adja, de a kutatás-fejlesztés és innováció 80 százaléka is az iparban zajlik.

Általánosságban elmondható, hogy az Egyesült Államok még a 2008-as válság után is (2007-2012-ben) jobban teljesített termelékenységben az európai országoknál és az OECD-országoknál, s még 2007-2009 között is képes volt növelni termelékenységét, amikor az euróövezetben visszaesés mutatkozott (1. ábra).

\section{1. ábra}

A munkaerő termelékenységének alakulása az OECD-ben és az euróövezetben, valamint néhány kiválasztott országban (1 órára jutó reál GDP éves növekedési üteme - százalék)

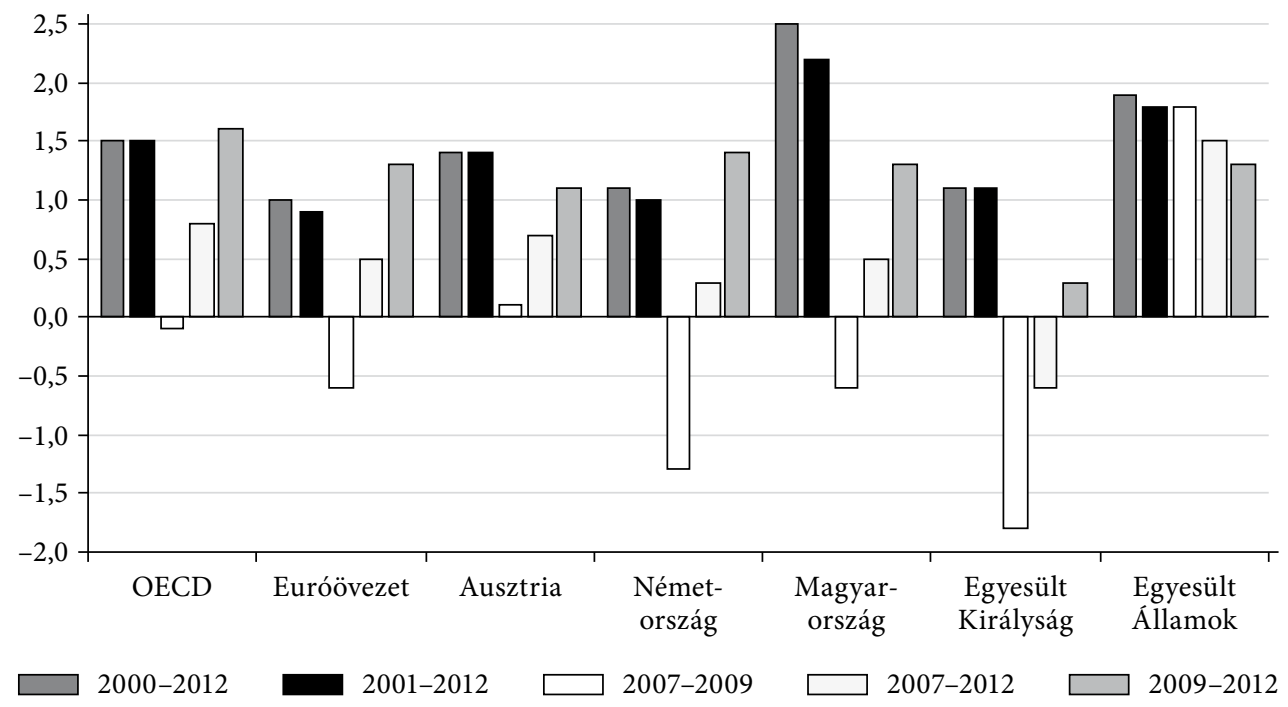

Forrás: OECD.Stat.

A hosszabb távú adatok jogossá teszik a kérdést: vajon miért nem járul hozzá a példátlan mértékü digitalizáció a termelékenység egyre látványosabb javulásához? A 3. ábra az IKT-használat szerint három csoportba sorolt iparágaknak (IKT-használó, nem IKTintenzív, valamint IKT-elöállító) az össztermelékenység növekedéséhez való hozzájárulását mutatja be. Látható, hogy az infokommunikációs technológiát használó iparágakban érdemben nem javult a munkaerő termelékenysége (egy foglalkoztatottra jutó hozzáadott érték növekedése). A helyzet még súlyosabb, ha a 2008 után bekövetkező válság időszakával is kalkulálunk, amikor nemcsak az Egyesült Államokban, de az EU motorjául szolgáló Németországban, illetve a pénzügyi központként szolgáló Egyesült Királyságban is visszaesést lehetett tapasztalni (van Ark és szerzőtársai [2016]).

Ha a termelési volumen alakulását az ipar 4.0 szempontjából is releváns szektorokat tartalmazó, mélyebb iparági bontásban tekintjük (4. ábra), látható, hogy a 2008-as válságot megelözően is inkább romló tendencia érvényesült (kivéve a járművek és szállítóeszközök gyártását). A válságot követő élénkítési programok csak átmenetileg serkentették az európai ipari termelést, a 2010-es rövid fellendülést a lanyhulás időszaka váltotta fel. A termelési volumenek változását tekintve láthatjuk, hogy 2015-re csak a 
2. ábra

Egy órára jutó bruttó hozzáadott érték (termelői szektor, éves százalékos változás)

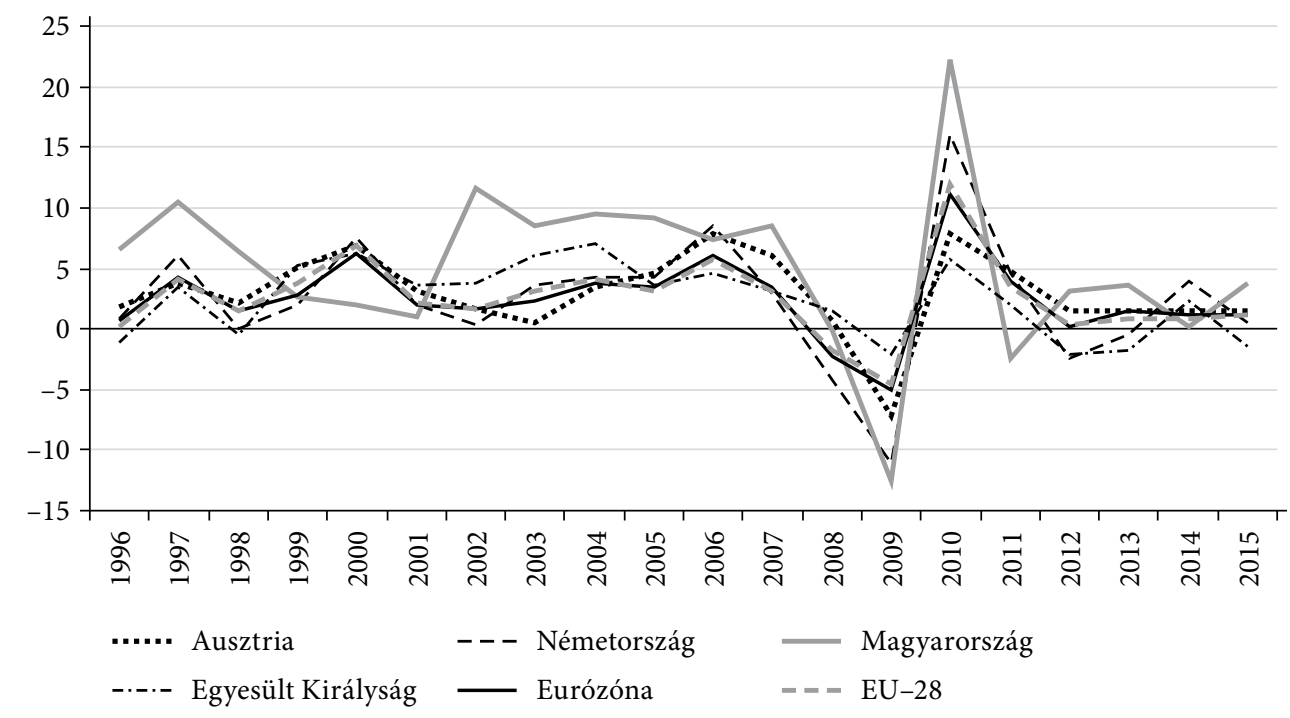

Forrás: OECD.Stat.

3. ábra

A munkaerő termelékenységének növekedése az IKT-használat szerinti szektorokban (évenkénti átlagos százalékpontos változás az adott időszakban)

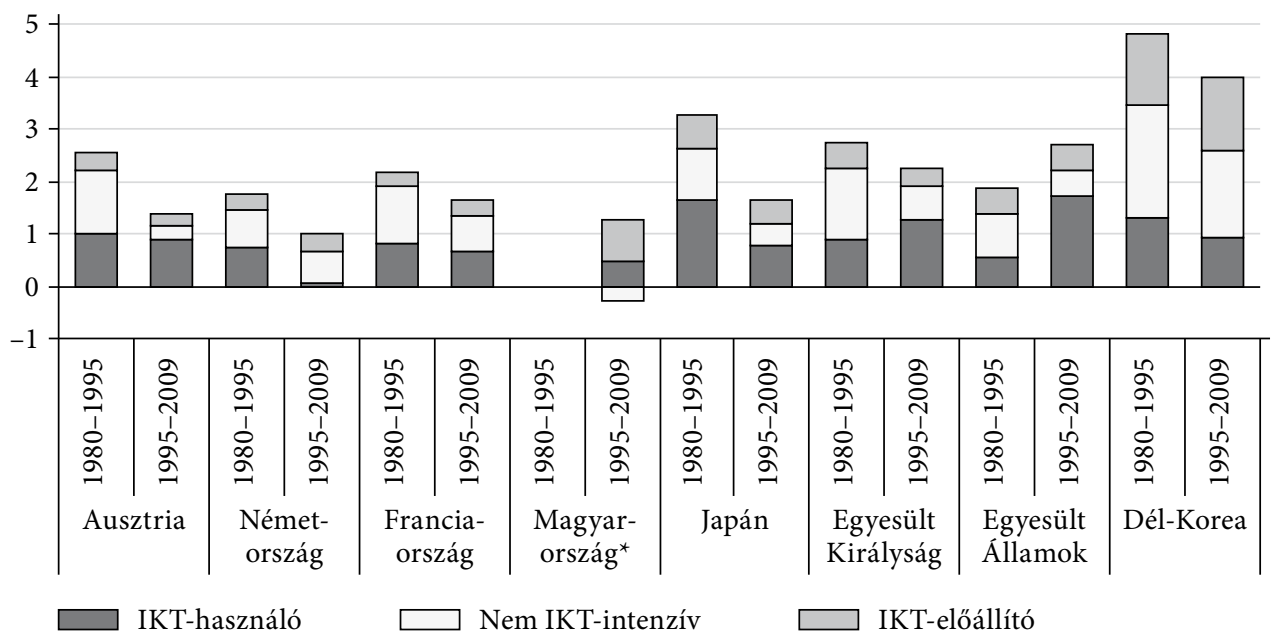

Megjegyzés: IKT-használó iparágakon az IKT-használók ama felső felét értjük, ahol a legmagasabb az IKT-ba való beruházás és az IKT-szolgáltatások beszerzése. Nem IKT-intenzívek az alsó felet képviselő iparágak. Az IKT-előállítókat külön is föltüntettük.

* Magyarország 1980-1995 közötti időszakára nem áll rendelkezésre adat. Forrás: OECD.Stat és EUKlems kalkulációk alapján. 
4. ábra

Releváns iparágak termelési volumenének változásai az EU-28-ban (százalék)

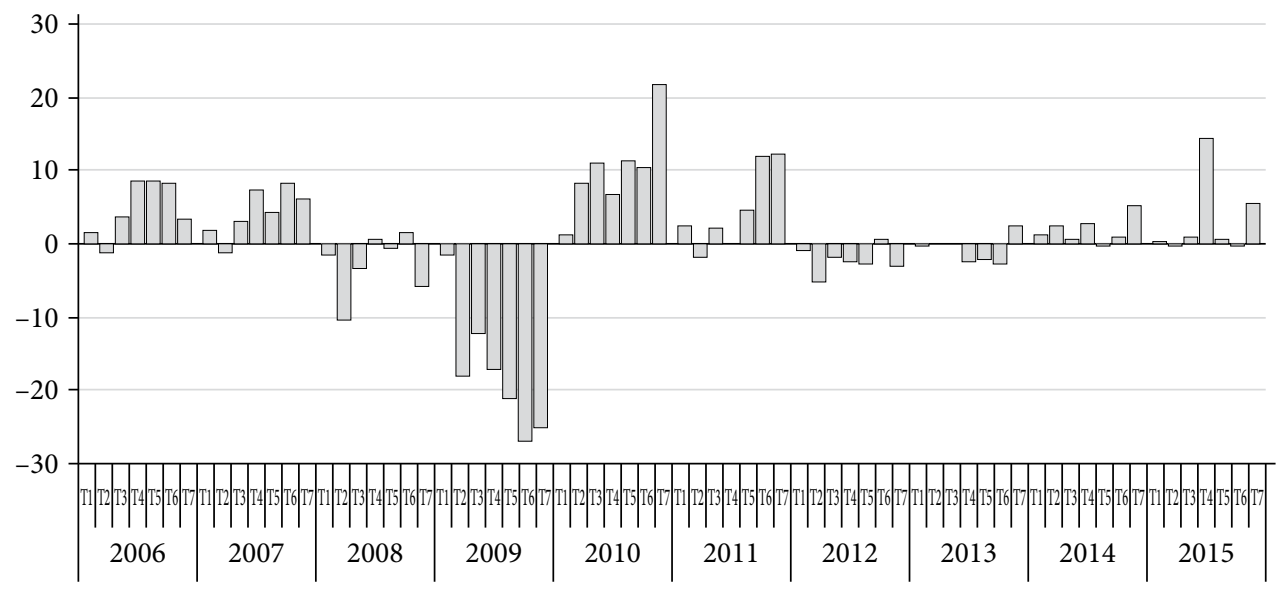

T1: Élelmiszer-, dohánytermék- és italgyártás

T2: Textilgyártás

T3: Vegyi anyagok és vegyi termékek gyártása

T5: Elektromos berendezések gyártása

T6: Gépek és eszközök gyártása

T7: Járművek és szállítóeszközök gyártása

T4: Számítógép, elektronikai, optikai termékek gyártása

Forrás: Eurostat.

számítógép, az elektronikai és optikai termékek gyártása bővült évi 10 százalékot is meghaladó mértékben. Ez a szektor csak Németországban és Ausztriában könyvelhetett el 2006-2015 között átlagosan 5 százalékos növekedést (5. ábra). Franciaország és az Egyesült Királyság viszont szinte mindegyik iparágban átlagosan és tartósan roszszabb mintázatot követ, mint a többi vizsgált ország, ami burkoltan utal innovációs teljesítményükre is. Kína pedig tudta tartani korábbi szintjét.

A 6. ábra az Egyesült Államokhoz viszonyítva mutatja be, hogyan alakult a teljes tényezőtermelékenység 2006-2014 között (ez az indikátor - hibái ellenére - közvetíti az országok innovációs képességét). A vizsgált európai gazdaságok nem tartottak lépést az Egyesült Államok termelékenységével, közülük Magyarország mozgott a legalacsonyabb szinten.$^{28}$ Eközben Dél-Korea növelte relatív helyzetét, Kína pedig tartotta korábbi szintjét.

Meg kell jegyeznünk, hogy a technológiai innovációk mellett felértékelödnek a nem technológiai újítások. Az infokommunikációs technológiára építő tudásgazdaságban a szolgáltatási szektorok adják a fejlett országok GDP-jének 70-80 százalékát, a fejlödőkének 50-60 százalékát (Glushko [2008]). Ez azért okvetlenül fontos most, mert az aggregált termelékenység romlását a szolgáltató szektorokban tapasztalható termelékenységi romlással magyarázzák a legfrissebb mikroszintű kutatások. ${ }^{29}$

${ }^{28}$ Az európai innovációs rangsor (European Innovation Scoreboard, 2017) szerint Magyarország a mérsékelt innovátorok csoportjába tartozik (http://ec.europa.eu/growth/industry/innovation/factsfigures/scoreboards_hu).

${ }^{29}$ A 2000 -es évek eleje óta erőteljesebben nő a jól teljesítő (global frontier) vállalatok és a lemaradók közti termelékenységi rés. Utóbbiak még jobban divergálnak a szolgáltató szektorok esetében, kü- 


\section{5. ábra}

Néhány releváns iparág termelési volumenének átlagos változása 2006-2015 között (százalék)

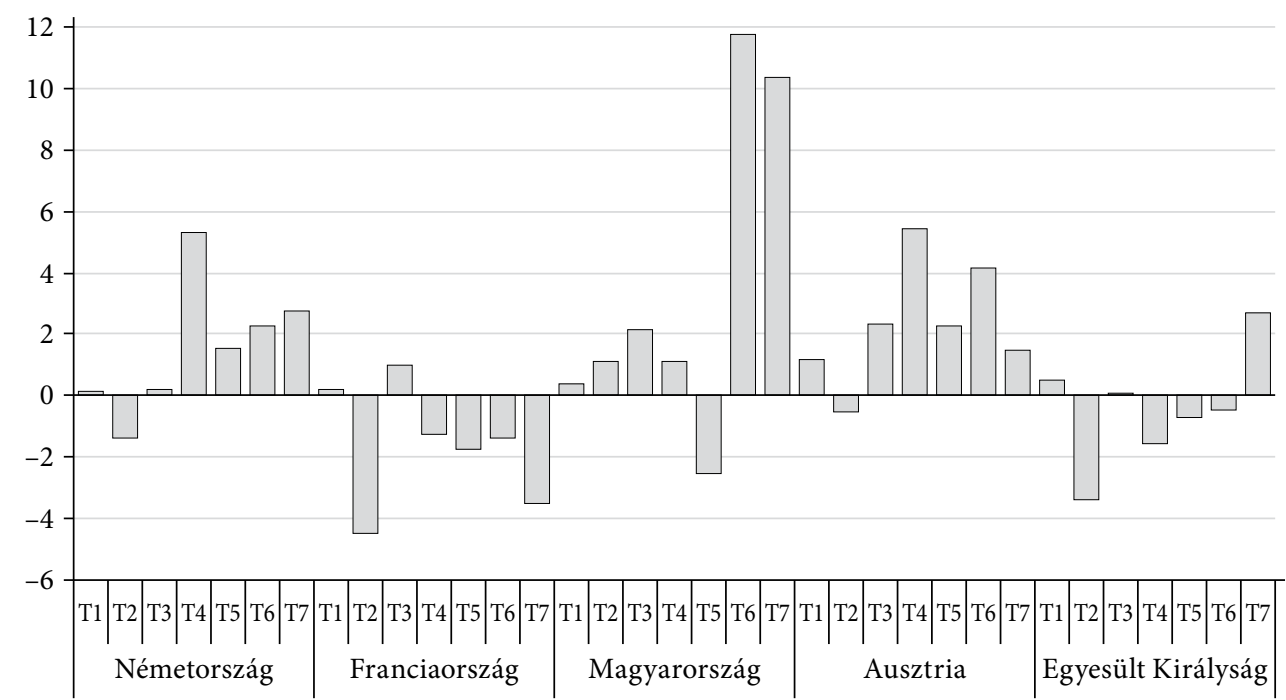

T1: Élelmiszer-, dohánytermék- és italgyártás

T2: Textilgyártás

T3: Vegyi anyagok és vegyi termékek gyártása

T4: Számítógép, elektronikai, optikai termékek gyártása
T5: Elektromos berendezések gyártása

T6: Gépek és eszközök gyártása

T7: Járművek és szállítóeszközök gyártása

Forrás: Eurostat.

Egyre több termelö/gyártó vállalat nyújt szolgáltatásokat termékéhez (servitisation of manufacturing). A digitális transzformáció fokozatosan bontakozik ki, és az erőteljesen heterogén digitális iparágak (hardvereket, szoftvereket gyártó, e-kereskedelemmel foglalkozó és vezeték nélküli szolgáltatásokat nyújtó vállalkozások) foglalkoztatottjainak száma 2001 óta folyamatosan növekszik. Becslések szerint 2011-ben a digitális iparágak 8,7 millió, többnyire magasan képzett embert foglalkoztattak az Európai Unióban (KetelsProtsiv [2014]). Az ipar 4.0 megjelenésének és elterjedésének ez a fajta digitalizáció természetesen elöfeltétele. Már most kimutatható, hogy kulcsfontosságú iparágak emelkednek ki az infokommunikációs technológiára építő ipar 4.0 kapcsán is: csomagolástechnológiai szektor, biogyógyszeripar, kék iparágak (tengeri kereskedelmen és vízi tevékenységeken nyugvó új iparágak), kreatív iparágak, környezetvédelem-központú iparágak, tapasztalati vagy élményiparágak (experience industries), logisztikai szolgáltatások, orvosi müszerek, mobilitást támogató technológiák. Ketels-Protsiv [2014] szerint ezekben az iparágakban dolgozik az EU-ban foglalkoztatottak 22 százaléka.

Az Európai Bizottság kulcsfontosságú alaptechnológiák (Key Enabling Technologies, KETs) adatbázisa alapján az 1. táblázat áttekinti, miképpen változott 2005 és 2013 között a foglalkoztatottak aránya a fejlett gyártástechnológia, a korszerủ anyagok és

lönösen az intenzíven infokommunikációs technológiai szolgáltatásokat kínáló szektorokban tágult legdinamikusabban a rés közöttük (Andrews és szerzötársai [2016]). 
6. ábra

A teljes tényezőtermelékenység alakulása (Egyesült Államok=1, vásárlóerő-paritáson)

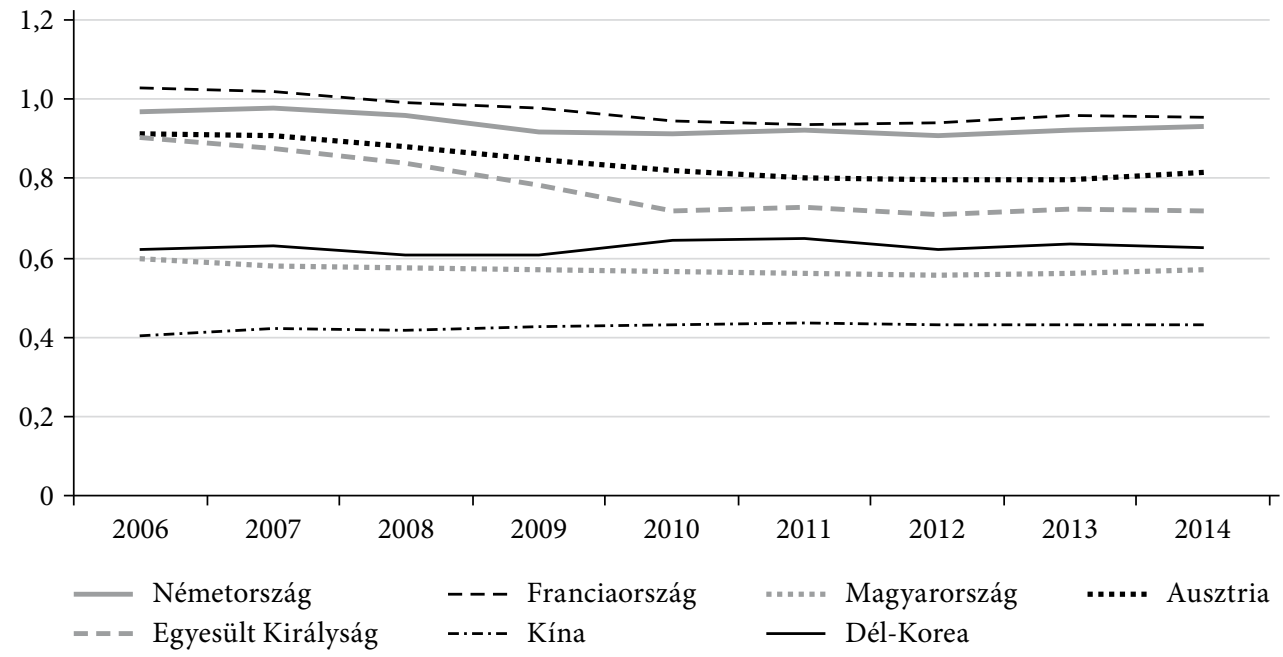

Forrás: Penn World Table.

1. táblázat

A foglalkoztatás alakulása néhány releváns iparágban (a teljes foglalkoztatás százalékában)

\begin{tabular}{lll}
\hline Ország & 2005 & 2013
\end{tabular}

Fejlett gyártástechnológia

Franciaország

7,6

8,8

Magyarország

6,9

5,4

Németország

8,4

8,2

Egyesült Királyság

5,6

6,5

Korszerü anyagok

Ausztria

4,1

4,0

Franciaország

3,7

4,2

Magyarország

6,9

5,3

Németország

4,1

5,1

Egyesült Királyság

3,5

3,8

Ipari biotechnológia

Ausztria

0,2

1,1

Franciaország

0,2

1,3

Magyarország

0,7

0,9

Németország

0,3

0,8

Egyesült Királyság

0,5

1,1

Forrás: KETs adatbázis. 
az ipari biotechnológia terén Ausztriában, az Egyesült Királyságban, Franciaországban, Magyarországon és Németországban.

A fejlett gyártástechnológia területén a teljes foglalkoztatáson belül a legalacsonyabb szintet 2005-ben Ausztria, míg a legmagasabbat Németország képviselte. 2013-ra az arányok mindenütt növekedtek, kivéve az eleve magas szinten álló Németországban, Magyarországon azonban nagyobb mértékü csökkenés volt. A korszerü anyagok területén 2005-ben a legnagyobb arányban Magyarország foglalkoztatott a vizsgált országok között, a legkisebb arányban pedig az Egyesült Királyság. 2013-ban Magyarország továbbra is kimagaslott, de már nagyfokú visszaesés következett be a 2005-ös értékéhez képest; $s$ továbbra is az Egyesült Királyságban maradt a legalacsonyabb a ráta. Az ipari biotechnológia területén tapasztalható a legdinamikusabb elörelépés a foglalkoztatás alakulását tekintve. Minden általunk vizsgált országban növekedést lehetett regisztrálni 2005 és 2013 között.

Összességében tehát igen eltérő dinamikáról beszélhetünk az egyes uniós országokban. Az ipar 4.0 és a digitális gazdaság müködtetéséhez - hatékony beavatkozási lehetőségek kimunkálásához - érdemes jobban megérteni a különbözö tendenciák mozgató mechanizmusait.

\section{Az európai ipar helyzete - a tendenciák mozgató mechanizmusai}

Az ipar 4.0, valamint a digitális gazdaság technológiai és nem technológiai megoldásai egyaránt az innovatív vállalkozói szellem generális tevékenységének az eredményei. (A kutatás-fejlesztés és innováció adja tehát a társadalmi-gazdasági rendszer dinamizmusát, amelyet azonban döntően befolyásolnak a kereslet és a kínálat, valamint az abszorpció és a diffúzió mechanizmusai. A következőkben e mechanizmusok európai jellemzőit igyekszünk röviden vázolni, mi befolyásolja az ipar 4.0 és a digitális gazdaságban rejlö lehetőségek kiaknázhatóságát.

\section{Kereslet és kínálat}

A kereslet jelenti az elsődleges jólétgeneráló hajtóerőt, ami mozgásba hozza a kutatásfejlesztési és innovációs tevékenységeket. Ennek kapcsán mindenképp érdemes számba venni a pénzügyi rendszer fejlettségét; minél fejlettebb a pénzügyi rendszer, annál inkább képes megjeleníteni és kiszolgálni az innováció iránti keresletet. Ehhez a vállalatok tőzsdei kapitalizációját, illetve a pénzügyi szektor által nyújtott hazai hitelállományt érdemes megnézni. Noha az EU28 vagy az Egyesült Államok pénzügyi rendszere fejlett, ki vannak téve kritikus instabilitásoknak. A pénzügyi szféra túlterjeszkedett a reálgazdaságon, ma már nem elsősorban pénzügyi közvetítő és a reálszektor termelékenységét előmozdító csatorna, amit jól mutatott a 2008-as pénzügyi és az azt követő reálgazdasági válság is. ${ }^{30}$

\footnotetext{
${ }^{30}$ A banki eszközállomány és a GDP növekedése elszakadt egymástól; a kihelyezett hitelállomány folyamatosan nőtt, miközben a termelékenység alig javult, azaz a hitelek hatékonysága csökkent, stb.
} 
Az Egyesült Államokban a forgalmazott értékpapírok összértéke a Lehman Brothers csődje előtt meghaladta a GDP 300 százalékát is, később megindult a konszolidáció, de még 2015-ben is 200 százalék fölött mozgott (7. ábra). Az említett magas értékek az európai országokra nem jellemzők. Tükröződik mindez a Buffettmutatóban - a hazai cégek tőzsdei kapitalizációjának alakulásán - is (8. ábra). Az Egyesült Államokban és az Európai Unióban publikált stressztesztekre reagáltak a piacok (Európában negatívan, lásd Candelon-Amadou [2015]), jelezvén, hogy bizonytalanság van a rendszerben.

\section{7. ábra}

Forgalmazott értékpapírok összértéke a GDP százalékában

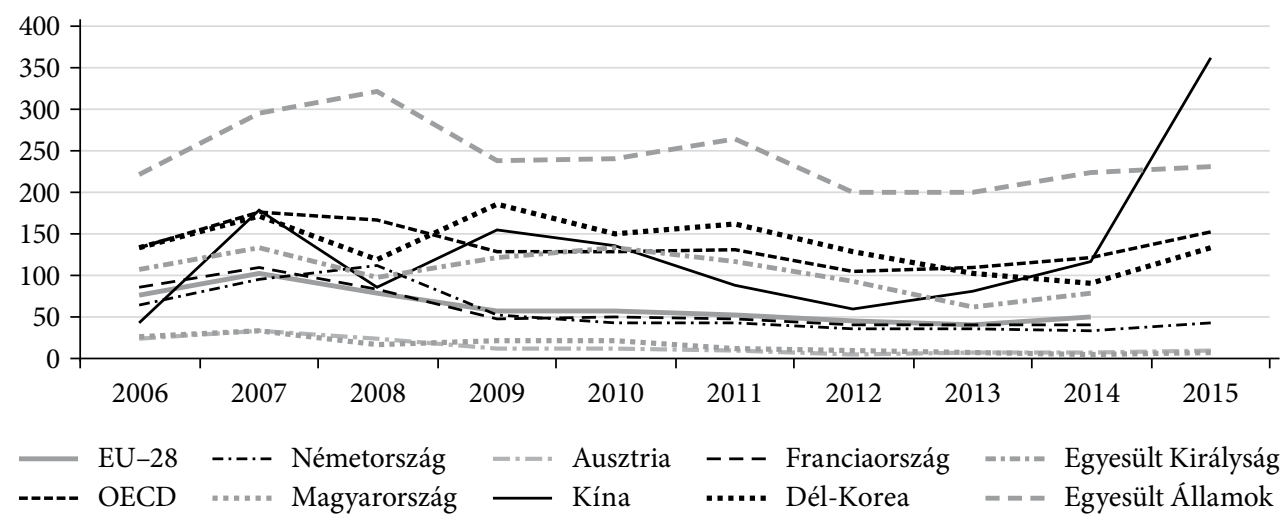

Forrás: World Bank, Development Indicators.

\section{8. ábra}

Tőzsdén jegyzett hazai társaságok piaci kapitalizációja a GDP százalékában

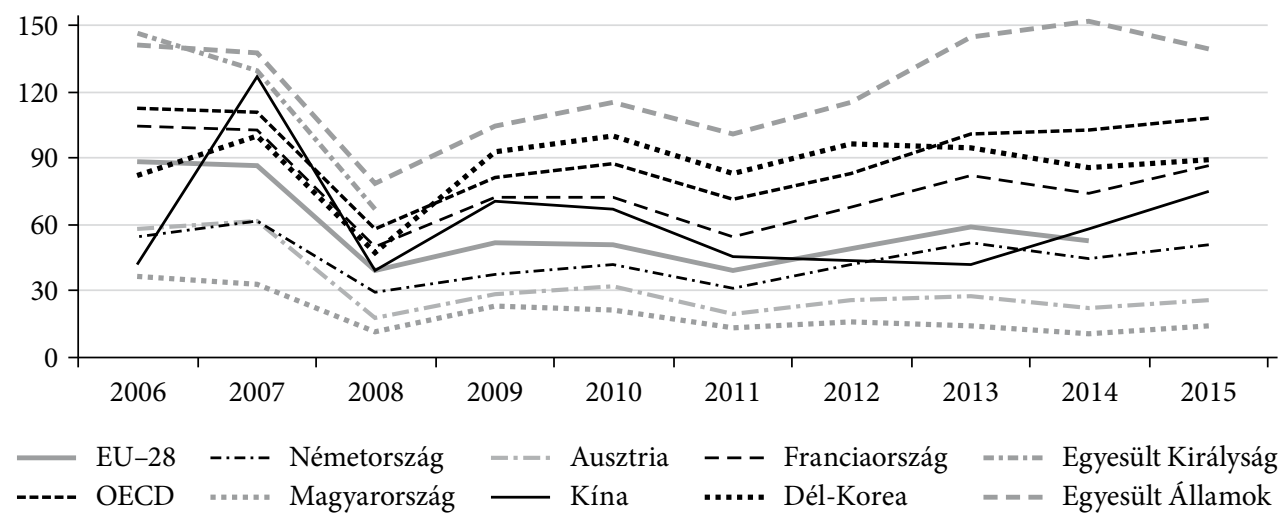

Forrás: World Bank, Development Indicators.

Közben elterjedtek a nem banki pénzügyi szervezetek, amelyek hozzásegítettek a buborékok, túlárazott eszközök kialakulásához (Abad és szerzőtársai [2017] 35. o.). 
Az ipar 4.0 kibontakozása a vállalati szektor szélesebb szegmensében, a kis- és középvállalkozások esetében kulcskérdés. Lehetőségeiket a pénzügyi szektortól kapott hitel e téren is befolyásolja (9. ábra). ${ }^{31}$ A mutató túl magas értéke (különösen a háztartási szektor esetén) elörevetíti a válságot; túl alacsony értéke a hazai vállalkozók kockázatkerülőbb voltára utal, mert a társadalmilag optimálisnál jóval kevesebbet ruháznak be $\mathrm{K}+\mathrm{F}-\mathrm{be}$, innovációba vagy már meglévő technológiák okos adaptációjába. ${ }^{32}$

9. ábra

A pénzügyi szektor által a hazai gazdaságnak nyújtott hitelállomány a GDP százalékában

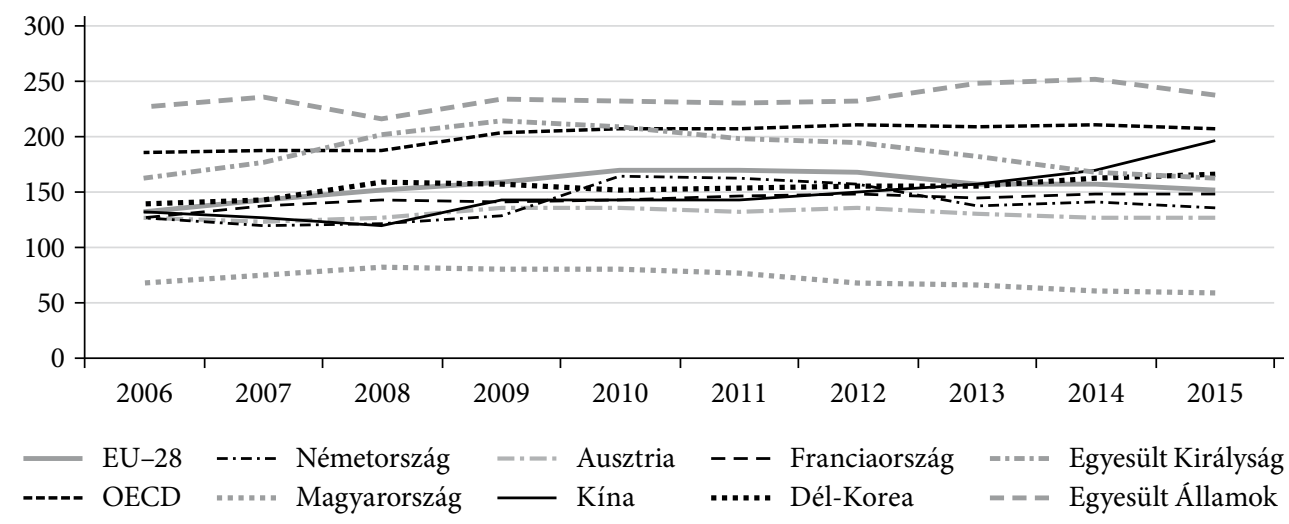

Forrás: World Bank, Development Indicators.

A makrogazdasági stabilitást is érdemes megvizsgálni, amihez szükség van megfelelő állami szabályozásra és a bizonytalanságcsökkentő intézmények működésére (Knight [1921]). Ez kulcsfontosságú az egészséges innovációs dinamizmus szempontjából (Bachmann és szerzőtársai [2013]). E tekintetben most csak röviden utalunk az Európai Bizottság által készített makrogazdasági egyensúlytalansági vizsgálatokra (Macroeconomic Imbalance Procedure). A 2013-as jelentés Magyarország, Franciaország és még Németország esetében is egyensúlytalanságot állapított meg. ${ }^{33}$ A 2014. évi jelentés határozott szakpolitikai beavatkozások szükségességéről szólt Magyarország és Franciaország esetében, míg Németország és az Egyesült Királyság esetében az egyensúlytalanság további elemzésének szükségességét hangsúlyozta (EC [2014]). A 2016-ra vonatkozó jelentés pedig a mélyebb elemzések elengedhetetlen voltára figyelmeztetett az általunk említett uniós országok mindegyikében, Ausztria esetében elsősorban a pénzügyi szektor teljesítménye miatt (EC [2015] 4. o.).

${ }^{31} 58$ ország 1960 és 2015 közötti vizsgálata azt mutatja, hogy az 1990-es évektől kezdve túllépték a GDP 90-95 százalékának megfelelő hitelállományt, majd ez az érték csak nőtt (lásd Chong és szerzőtársai [2017]).

${ }^{32}$ Magyarországon ez a bizonytalanság kimutatható (Kovács [2015b]), a kis- és középvállalkozások hitelállománya folyamatosan csökkenő tendenciájú volt 2009 és 2014 között (Bálint és szerzőtársai [2015]).

${ }^{33}$ Németország esetében a folyó fizetési mérleg méretes többlete vetette fel a mélyebb elemzés szükségességét (EC [2013]). 
A kereslet-kínálati mechanizmus közt reflexív kölcsönhatás van, a következőkben a kutatás-fejlesztés és innováció kínálatát befolyásoló tendenciákat emeljük ki. A kínálat nemcsak a tudás generálása, de a tudás és a technológia felszívása szempontjából is fontos kérdés. Épp ezért az egyik legfontosabb immateriális eszközberuházási kategóriára (intangible capital investment), ${ }^{34} \mathrm{a} \mathrm{K}+\mathrm{F}$ és innovációra fordított kiadásokat (GERD), azon belül pedig különösen az üzleti szektor által e területre fordított kiadások arányát vesszük szemügyre, kiegészítve a kutatók számának alakulásával. A 10. ábrán a GERD-mutató esetében látszik, hogy trendje 2009-ben megtört a vizsgált uniós országokban, a legmagasabb a német és az osztrák érték. Fontos látni, hogy Németországban ebből 66 százalékot az üzleti szektor finanszíroz, míg Ausztriában csak 46 százalékot - ami a magyar vagy a brit szint (11. ábra).

10. ábra

$\mathrm{K}+\mathrm{F}$ és innovációs bruttó hazai kiadások a GDP százalékában (GERD)

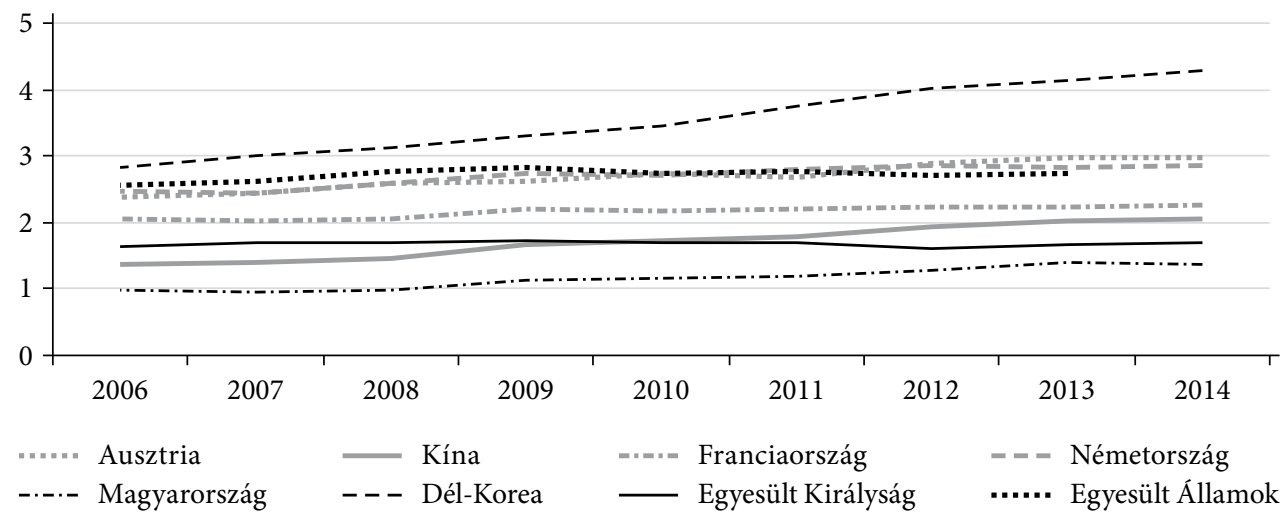

Forrás: UNESCO.

11. ábra

Üzleti szektor K+F és innovációs bruttó kiadása (GERD, százalék)

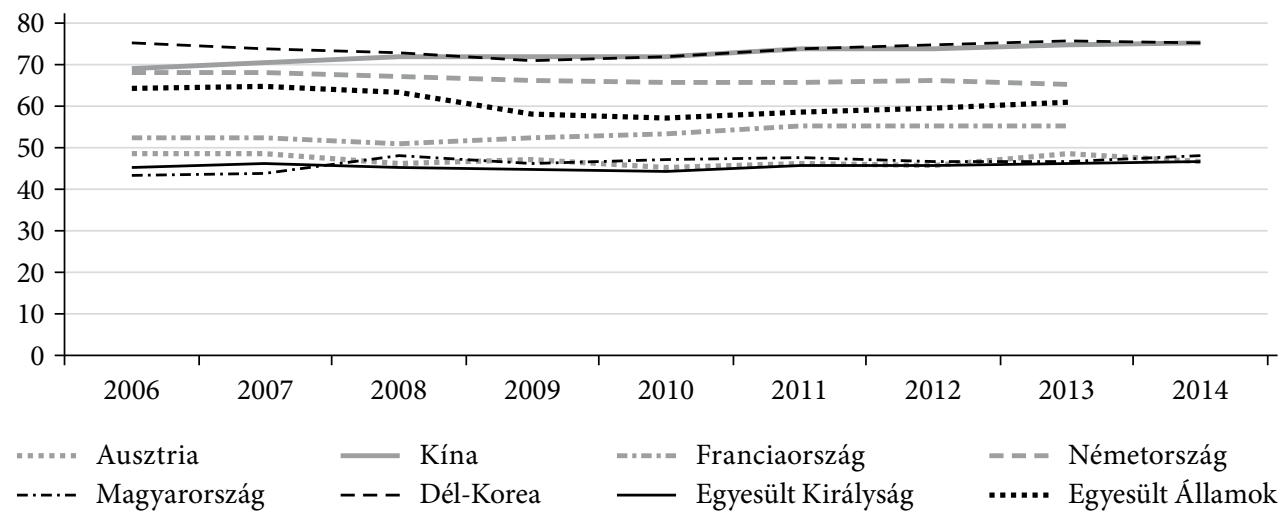

Forrás: UNESCO.

${ }^{34}$ E beruházások termelékenység-, illetve jóllétjavító hatása régóta ismert (Innodrive [2011]). 
A transzformatív erejü ipar 4.0 és a digitális gazdaság kiépítéséhez tehát az államnak nagyobb volumenü pótlólagos költségvetési ösztönzőket is be kell vetnie az alacsonyabb üzleti $\mathrm{K}+\mathrm{F}$ és innovációs kiadásokhoz szokott országokban (az immateriális tőkeberuházás ne csak a szolgáltató szektorban növekedjék erőteljesen, lásd Corrado és szerzötársai [2016]). Mindez költségvetési mozgásteret feltételez, vagy éppenséggel a befektetők szemléletbeli paradigmaváltását a deficit- és adósságfinanszírozással kapcsolatban: az ilyen eladósodás értékteremtő beruházás lehet a jövőbe. ${ }^{35}$

Bár a $\mathrm{K}+\mathrm{F}$ és az innováció területén dolgozók száma növekszik a vizsgált uniós országokban (12. ábra), az ipar 4.0 által igényelt adattudósi bázis (data scientists) bővítésére a felsőoktatásnak kell felkészülnie, amihez többletforrások szükségesek. ${ }^{36}$

\section{2. ábra}

Ezer munkaképes korúra jutó K+F-személyzet száma

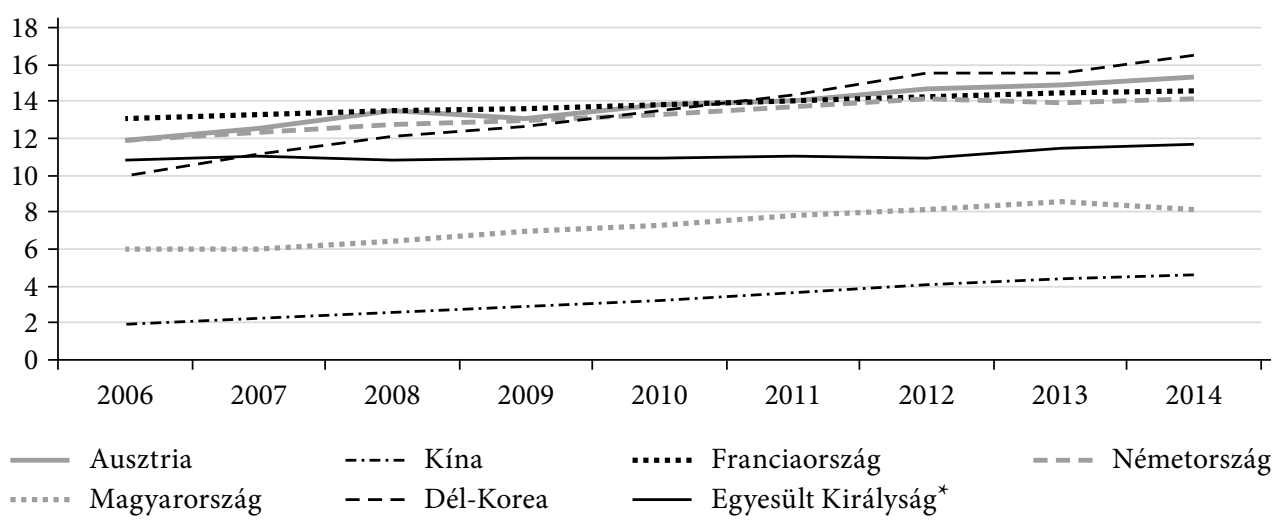

* Az Egyesült Királyság adatai még nem álltak rendelkezésre. Forrás: UNESCO.

\section{Abszorpció és diffúzió}

Az abszorpció az adott egyén vagy szervezet számára szükséges konkrét tudás változatlan formában történő felszívását és alkalmazását jelenti, amelyben a tanulásnak, a képességek továbbfejlesztésének szerepe van. Ehhez képest a diffúzió a helyi körülményekhez igazított, továbbfejlesztett - tehát nem változatlan formájú tudás elterjedését jelenti.

$\mathrm{Az}$ abszorpciós kapacitás megragadható azáltal is, ha az oktatásra koncentrálunk. Az oktatás és képzés révén javítható az emberi tőke minősége, ami képessé

${ }^{35}$ Lásd az ENSZ Társadalmi Fejlődési Kutatóintézetének (United Nations Research Institute for Social Development, UNRISD) egyik legátfogóbb jelentését, amelyben a hazai költségvetési források hatékony felhasználásáról írnak (UNRISD [2016] 167-195. o.).

${ }^{36} 2016$ első felében az adattudósok iránti igény 45 százalékkal nőtt az EU-ban, elsősorban a termelőszektorban, de a pénzügyi szektorban is (Procorre [2016]). 
teszi a szervezeteket az adaptációkra. S mivel a termelékenység és a növekedés egyre jobban függ az immateriális eszközökbe való beruházásoktól (amelyek legtöbbje emberitőke-intenzív), ezért lényeges az oktatásra fordított kiadásokkal foglalkoznunk. ${ }^{37} \mathrm{Az}$ ipar 4.0 és a digitális gazdaság nem müködik kreatív, képzett, tanulással váltani kész munkaerő nélkül. A kiadások puszta nagyságánál természetesen az oktatási rendszer minőségét kellene elemezni az ipar 4.0 szempontjából (Kovács [2016]). A következő ábrákon szemléltetjük a kiadási szintek, valamint az oktatási rendszerek minőségi és hatékonyságbeli problémáit kiváltó folyamatokat, ${ }^{38}$ ugyanis modernizáció és pótlólagos beruházások nélkül aligha érhető el magas fokú abszorpciós kapacitás az EU-ban: 1. a kiadásokat 2009 óta csökkentik az EU-ban (13. ábra), 2. a felsőfokú tanulmányokat folytatók aránya szinten maradt (14. ábra), 3. továbbra is nagy hiányosságok vannak a digitális készségek terén. (Az Eurostat-adatai szerint például 2015-ben az EU munkaeröállományának 37 százaléka nem rendelkezett kielégítő szintủ digitális készségekkel, 13 százalék pedig egyáltalán nem rendelkezett digitális kompetenciákkal.) A felsőoktatási rendszerek nem igazodtak hozzá a digitális kor, az ipar 4.0 követelményeihez (interdiszciplináris együttmüködések, tömeges online kurzusok, digitális készségek fokozott fejlesztése stb.).

\section{3. ábra}

Oktatásra fordított kormányzati kiadások a GDP százalékában

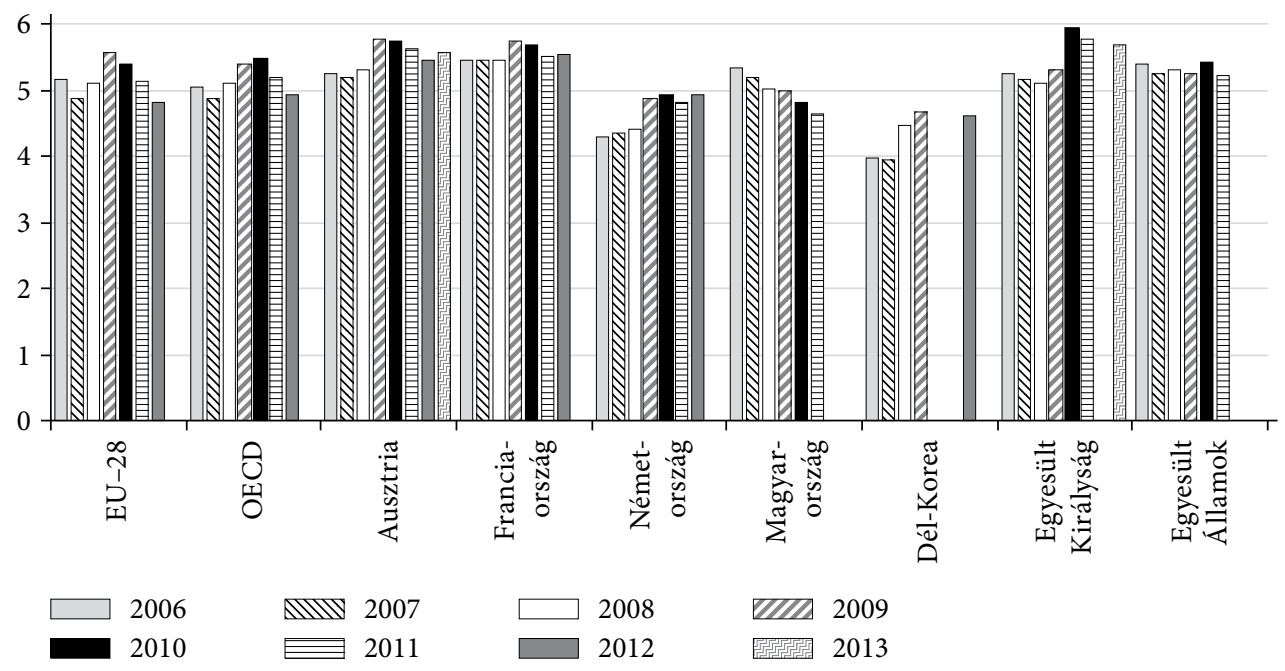

Forrás: World Bank, Development Indicators.

${ }^{37} 1995$ és 2007 között az immateriális eszközökbe történő beruházások (készségek, képesítés, szervezeti know-how, menedzsment-szakértelem, szoftverek, adatbázisok, dizájn, szellemi tulajdon stb.) 20 százalékkal növelték a termelékenységet az EU-ban, körülbelül 37 százalékkal Egyesült Államokban (OECD [2013]).

${ }^{38}$ Ezt hangsúlyozza $E C[2016 b]$ is, amely az új európai készségfejlesztési program szükségességéről is értekezik. 


\section{4. ábra}

Felsőfokú tanulmányokat folytatók százalékaránya (mindkét nem esetén, százalék)

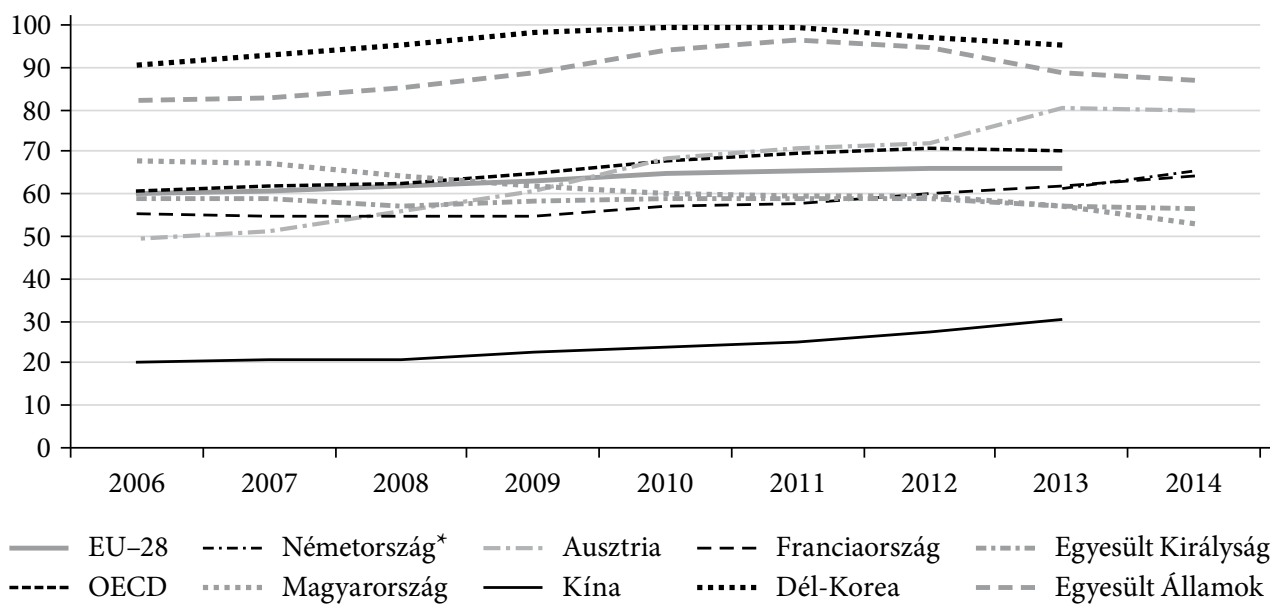

* Nem állnak rendelkezésre adatok a 2013 előtti évekből Németország esetében.

Megjegyzés: az indikátor azt méri, hogy a középszintű tanulmányokat befejezők - kortól függetlenül - a végzést követő 5 éven belül milyen arányban iratkoznak be felsőfokú tanulmányok folytatására.

Forrás: World Bank, Development Indicators.

A diffúziót elemezve az ipar 4.0 vagy a digitális gazdaság szempontjából az internethasználatot érdemes górcső alá venni, de annál is értékesebb információkat közölhet az, hogy vajon milyen könnyen képesek a vállalatok üres álláshelyeiket IKT-specialistákkal feltölteni, akiknek oroszlánrészük van a digitális átállás előmozdításában. Az internethasználat folyamatosan növekedett az EU-28-ban (15. ábra). Magyarországon 2015ben kisebb visszaesés mutatkozott, az Egyesült Államok e téren pedig mintha „beragadt" volna 2006 és 2015 között. Némely tanulmány azt hangsúlyozza, hogy az internethasználat pozitív hatása erősen függ egy olyan diffúziótól, amelynek során az ipar 4.0 világa fel tudja ölelni a kevésbé termelékeny vállalati szegmenset is, és meg tudja támogatni az inkluzív növekedést (Pilat-Nolan [2016] 120. o.).

Az EU-tagországokban a vállalkozások nehézségekbe ütköznek a megfelelő IKTspecialisták felvétele terén: 2014-ben az IKT-specialistát kereső cégek 38 százaléka alig tudta feltöltetni az álláshelyeket (Eurostat [2016]). A vállalati bontás még súlyosabb képről árulkodik (2. táblázat), ugyanis a foglalkoztatottak döntő részéért felelős kis- és középvállalkozások terén az IKT-specialisták alkalmazása inkább stagnál, mintsem növekedne. A nagyvállalati szegmensben inkább a bővülés jelei látszanak, negatív tendencia csak az Egyesült Királyságban észlelhetö.

Fontos kiemelnünk azt a tényt, hogy a fejlett világban (így például az Egyesült Államokban, az euróövezet országaiban vagy az Egyesült Királyságban) a 2000-es évek elejétől kezdődően leállt az IKT diffúziója (Cette és szerzőtársai [2015]). Továbbá az is igaz, hogy az IKT-diffúzió lassabb és alacsonyabb hatékonyságú Európában, mint az Egyesült Államokban (Cette és Lopez [2012], Cette és szerzötársai [2016], 
15. ábra

Száz lakosra jutó internethasználók száma

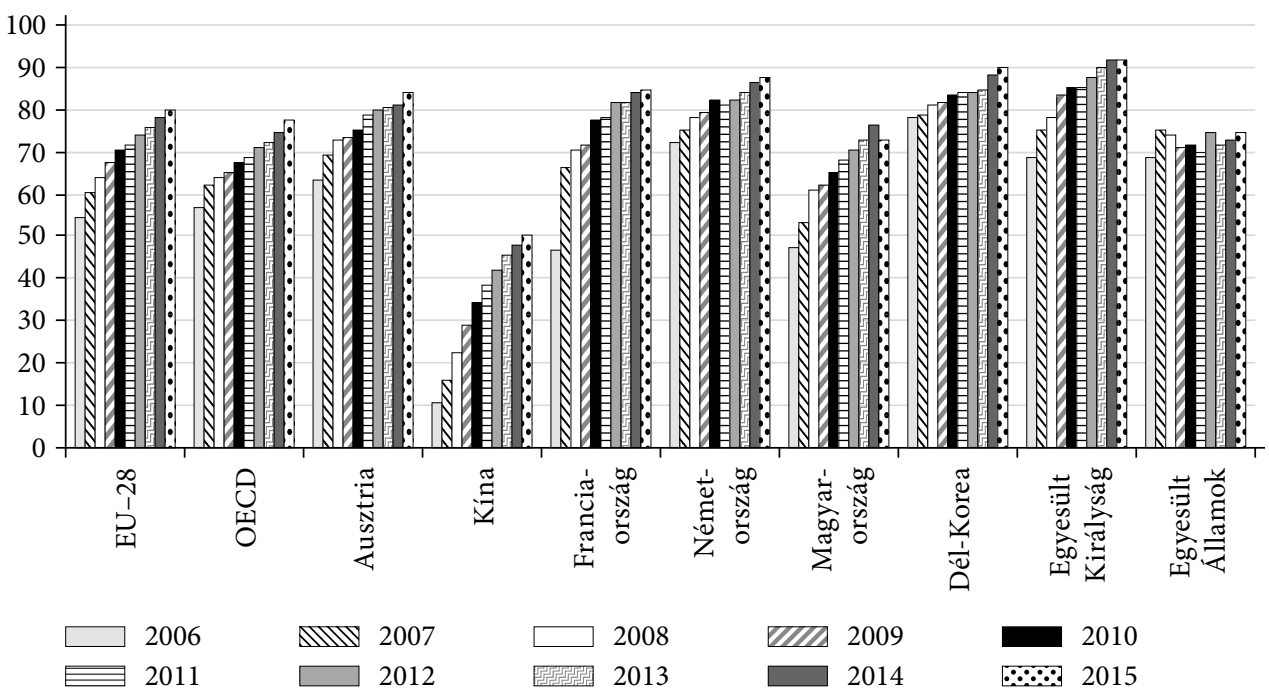

Forrás: World Bank, Development Indicators.

\section{2. táblázat}

IKT-specialistát alkalmazó vállalatok százalékaránya

\begin{tabular}{lll}
\hline Ország & 2012 & 2015 \\
\hline
\end{tabular}

Kis- és középvállalkozások (10-249 fö foglalkoztatott)

Németország 19

Ausztria 30 22

Magyarország 29

Egyesült Királyság

29

Franciaország

13

15

Nagyvállalatok (250 főnél több foglalkoztatott)

Németország 83 82

Ausztria 87 89

Magyarország 66 82

Egyesült Királyság

81 71

Franciaország 71 77

Forrás: Eurostat [2016].

van Ark és szerzőtársai [2008]). A különbség legfontosabb okaiként a használat költségét, az oktatási hiányosságokat és a túlszabályozás miatti rugalmatlanságot emelik ki az idézett tanulmányok. Gondolhatunk itt a foglalkoztatásvédelem szabályozására, ami tipikusan magasabb az OECD-átlagnál Ausztriában, Németországban, 
Franciaországban, de még Magyarországon is, míg alacsonyabb az Egyesült Királyságban és az Egyesült Âllamokban. ${ }^{39}$ Itt említhető a szolgáltatások szabályozásának versenykorlátozó szigorúsága is (Andrews és szerzőtársai [2016]).

Egyre megalapozottabban feltételezhető az is, hogy az IKT-diffúzió súlypontja eltolódik a nagyvállalatok javára. Ma már a nagyvállalatok az első számú foglalkoztatók az EU-ban (az összes foglalkoztatott 33 százalékát adják, a 29,2 százalékát pedig a mikrovállalkozások). 2008 és 2016 között például az általunk is vizsgált EU-országok mindegyikében kimutatható volt, hogy a közepes méretű vállalkozások aránya csökkent, a mikrovállalkozásoké pedig csak enyhén nőtt (Muller és szerzőtársai [2016]). S mivel a termelékenység és a méret között korreláció van - az idézett Andrews és szerzőtársai [2016] újra megerősíti ezt -, ezért egyenlőtlenség van a vállalatok között $i s$, ami a termelékenység növelhetősége szempontjából további szakpolitikai beavatkozást igényel. Az innovációs ökoszisztéma inkább gátolja, mintsem elősegítené az infokommunikációs technológia elterjedését, azon keresztül pedig az ipar 4.0 technológiák és szolgáltatások diffúzióját.

A diffúziót a fizetőképes kereslet is befolyásolja, ebből a szempontból döntő jelentősége van a jövedelemegyenlőtlenség alakulásának. E tekintetben a trend az EU-28ban növekszik. A 16. ábra mutatja, hogy az EU-28-ban átlagosan több mint ötször annyi jövedelemhez jutnak hozzá a felső 20 százalékban lévő jövedelmi osztály tagjai, mint a legalsóban lévők.

16. ábra

Jövedelemegyenlőtlenség a felső jövedelmi ötödhöz képest

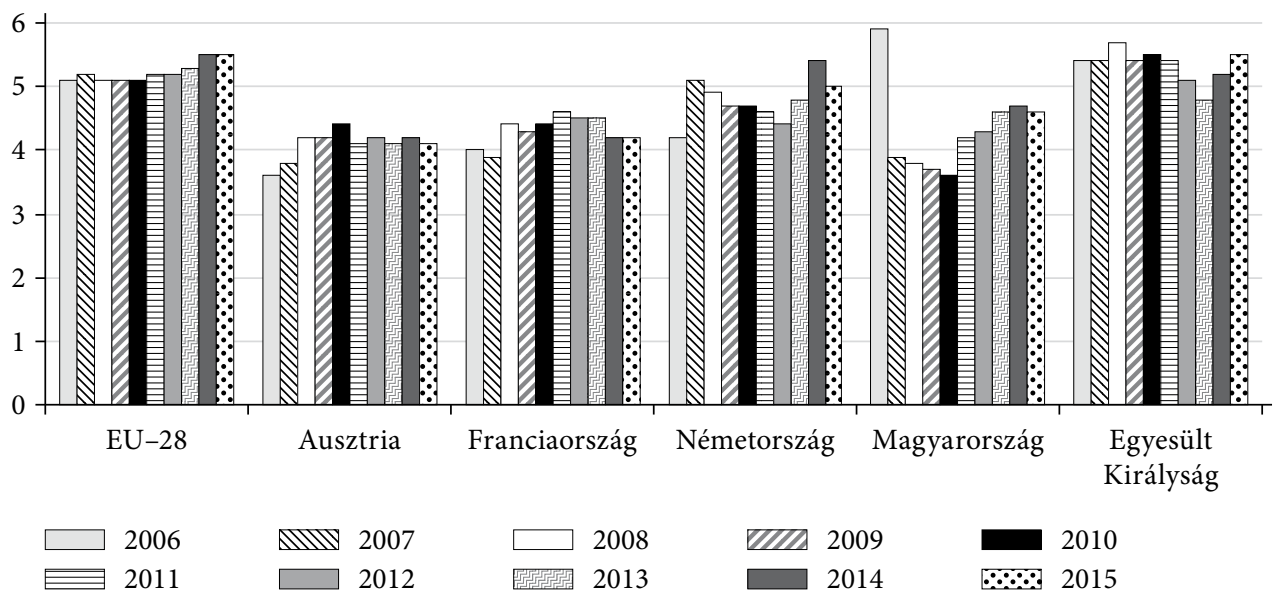

Megjegyzés: az ábra azt mutatja, hogy az alsó jövedelmi ötödhöz képest hányszor több jövedelemhez jutnak hozzá a legfelső ötödben lévők.

Forrás: Eurostat.

\footnotetext{
${ }^{39}$ OECD Employment Protection Indicator (http://www.oecd.org/els/emp/oecdindicatorsofemplo ymentprotection.htm). Az adatokból kiderül, hogy Dél-Korea az ázsiai válság után fellazította a foglalkoztatás védelmét.
} 
A jövedelemegyenlőtlenség növekedése és a gazdasági dinamizmus közt többnyire negatív a kapcsolat (Alesina-Rodrik [1994], Perotti [1996], OECD [2015b]). Az ipar 4.0-hoz köthető technológiai és nem technológiai innovációk diffúzióját - ami a növekedést lendületbe hozhatja - gátolja a növekvő jövedelemegyenlötlenség. Pozitív kapcsolat csak gazdag országokban volt egyes esetekben és bizonyos időszakokban kimutatható, ahol innovativitás révén a termelékenység növekedése ellensúlyozni tudta a negatív hatást, s a felső jövedelemosztályok jövedelemnövekedése kemény munkára és további kreativitásra ösztönzött, s még nem érintette nagyon károsan az alsóbb jövedelemosztályok megélhetését (Aghion és szerzőtársai [2015], AndersenMaibom [2016]). Vagyis, ahol az egyenlötlenség eleve magas, s további növekedésének, illetve az elszegényedés dinamikus folyamatának politikai stabilitást aláásó potenciálja van, ott a kapcsolat csak negatív lehet.

Ezen tendenciákat is figyelembe véve kell a szakpolitikának támogatnia az ipar 4.0 kibontakozását. Az ipar 4.0 egyik vezérmotívuma ugyanis az élő munkaerőt kímélő technológiának számító robotmunkaerő alkalmazása. Ezzel kapcsolatban fennáll a veszély, hogy az automatizálás, a robotika következtében az EU 80 millió föt számláló alacsony képzettségủ munkavállalói közül tömegesen kerülnek ki a munkaerőpiacról (Arntz és szerzőtársai [2016]). Az EU jelenleg vezető helyet foglal el a robotika terén, hiszen a 10 ezer munkásra jutó ipari robotok száma 18 uniós országban világátlagon felülinek számít. Európa a világ első számú szolgáltatórobot-gyártója (Európában 258 gyártót regisztráltak, Észak-Amerikában 226-ot, Ázsiában 112-t). ${ }^{40}$ De világtendencia, hogy nemcsak az ipari robotok iránti kereslet nö, hanem a különbözö szakmai területeken alkalmazható szolgáltató robotoké is (például robotok orvosi diagnózisokhoz, mütéti beavatkozásokhoz, rehabilitációhoz stb.), illetve a háztartásokban elöforduló robotok száma is dinamikus növekedést mutat (MGI [2013]).

\section{Záró gondolatok}

A Nobel-díjas Paul Krugman szerint a termelékenység nem minden, de hosszú távon majdnem az (Krugman [1997]). Rajta keresztül valósulhat meg a prosperitás, az állam állampolgárok számára tett jóléti ígérvényeinek teljesítése, az általános életszínvonal hosszú távú, fenntartható emelkedése. A termelékenységhez pedig transzformáció és változás kell. Jelen írás szerzője úgy véli, hogy a szakpolitika feladata többek közt olyan keretfeltételek és intézkedések kimunkálása, amelyek a változásnak úgy adnak teret, hogy annak pozitív következményei dominálhassanak. Ellenkező esetben a félelem- és a bizonytalanságérzés társadalmi ellenálláshoz, azon keresztül pedig komoly torzító hatásokhoz vezethet.

Az ipar 4.0 és a digitálizáció egy nyílt, adaptív, memóriával rendelkező, komplex társadalmi-gazdasági innovációs ökoszisztémában valósul meg. A kutató számára

\footnotetext{
${ }^{40}$ Lásd IFR World Robotics 2016. http://www.ifr.org/news/ifr-press-release/service-robotics-835/. Az Európai Unióban a PAN-Robots projekt automatizáltan irányított járművek tervezésével, kivitelezésével foglalkozik, és így a logisztika területén ígér előrelépést.
} 
ezért meglehetősen mérsékeltnek mondható minden olyan eddigi elemzés értéke, amelyek hajlamosak a pozitív hatásokat hangoztatni. Tanulmányunk I. része reményeink szerint világosság tette, hogy a kérdéskört a maga komplexitásában érdemes kezelni. Ezért a „nagyon egyszerü, csak meg kell csinálni!” elv alkalmazása káros lehet.

Megkerülhetetlennek gondoljuk azon kölcsönhatások feltérképezését, amelyek 1. potenciális átváltásokra, 2. általánosabb szinergiahatásokra és 3. nem szándékolt következményekre figyelmeztethetik a gazdaságpolitikai döntéshozókat. Ezek alapján holisztikusabb képet kaphatunk a jelen írásban csak fölvillantott potenciális következményekről is.

Valljuk, hogy inkább legyenek kérdéseink, amelyekre még nem tudjuk a válaszokat, mint hogy olyan végsőnek vélt válaszaink legyenek, amelyek könnyűszerrel megkérdöjelezhetők. Az európai ipar állapotának rövid áttekintése, valamint a legfontosabbnak vélt mechanizmusok feltérképezése további kérdéseket vet fel, és mélyebb elemzésre szólít. A cikkben említett kölcsönhatások komplex vizsgálata közelebb vihet ama lényegi kérdések tisztázásához, hogy vajon az ipar 4.0 és a digitális gazdaság aktív iparpolitikai kibontakoztatása technikailag megoldható-e, társadalmilag elfogadható-e, politikailag nem túl destabilizáló-e, valamint szakmailag kivitelezhetö-e.

A tanulmány II. része azokat a legfontosabb gazdasági kormányzási vezérelveket vázolja fel, amelyek a negyedik ipari forradalom és a digitális gazdaság fenntartható kibontakoztatását alapozhatják meg.

\section{Hivatkozások}

Abad, J.-D’errico, M.-Killeen, N.-Luz, V.-Peltonen, T.-Portes, R.-Urbano, T. [2017]: Mapping the Interconnectedness between EU Banks and Shadow Banking Entities. European Systemic Risk Board, Working Paper, No. 40. https://doi.org/10.3386/w23280.

AcAтесн [2013]: Deutschlands Zukunft als Produktionsstandort sichern. Umsetzungsempfehlungen für das Zukunftsprojekt Industrie 4.0. Az ipar 4.0. munkacsoport zárójelentése. Deutsche Akademie der Technikwissenschaften, https:/www.bmbf.de/files/Umsetzungs empfehlungen_Industrie4_0.pdf. (Lásd még: Final Report of the Working Group on Industry 4.0. http://booksreadingathome.com/downloads/acatech-final-report-of-the-industrie4-0-working-group.pdf.)

Асатесн [2015]: Umsetzungsempfehlungen für das Zukunftsprojekt Internetbasierte Dienste für die Wirtschafte. Deutsche Akademie der Technikwissenschaften, http:// www.acatech.de/fileadmin/user_upload/Baumstruktur_nach_Website/Acatech/root/de/ Projekte/Laufende_Projekte/Smart_Service_Welt/BerichtSmartService_mitUmschlag_ barrierefrei_HW76_DNK2.pdf.

Aghion, P.-Akcigit, U.-Bergeaud, A.-Blundell, R.-Hémous, D. [2015]: Innovation and Top Income Inequality. Harvard University, kézirat, http://dx.doi.org/10.2139/ ssrn.2617607.

Aghion, P.-Boulanger, J.-Cohen, E. [2011]: Rethinking Industrial Policy. Bruegel, Policy Brief, 2011/04.

Aiginger, K. [2015]: Industrial Policy for a Sustainable Growth Path. Megjelent: Bailey, D.-Cowling, K.-Tomlinson, P. (szerk.): New Perspectives on Industrial Policy for a Modern 
Britain. Oxford University Press, Oxford, 19. fejezet. 365-394. o. https://doi.org/10.1093/a cprof:oso/9780198706205.003.0019.

Alesina, A.-Rodrik, D. [1994]: Distributive Politics and Economic Growth. The Quarterly Journal of Economics, Vol. 109. No. 2. 465-490. o. https://doi.org/10.2307/2118470.

Andersen, T. M.-Maibom, J. [2016]: The Big Trade-Off between Efficiency and Equity - Is it There? CEPR Discussion Paper, No. 11189.

Andrews, D.-Criscuolo, C.-GaL, P. A. [2016]: The Global Productivity Slowdown, Technology Divergence and Public Policy. Brookings Institute, Hutchins Center Working Paper, No. 24.

Arntz, M.-Gregory, T.-Zierahn, U. [2016]: The Risk of Automation for Jobs in OECD Countries: A Comparative Analysis. OECD Social, Employment and Migration Working Papers No. 189. OECD Publishing, Párizs, https://doi.org/10.1787/5jlz9h56dvq7-en.

Bachmann, R.-Elstner, S.-Sims, E. R. [2013]: Uncertainty and Economic Activity: Evidence from Business Survey Data. American Economic Journal, Macroeconomics, Vol. 5. No. 2. 217-249. o. https://doi.org/10.1257/mac.5.2.217.

BÁlint Máté-Fellner Zita-OláhZsolt [2015]: Hitelezési folyamatok. Magyar Nemzeti Bank, augusztus, https://www.mnb.hu/letoltes/hitelezesi-folyamatok-201508-hu.pdf.

BCG [2015]: Industry 4.0: The Future of Productivity and Growth in Manufacturing Industries. BCG Perspectives. Boston Consulting Group, https://www.bcgperspectives.com/content/articles/engineered_products_project_business_industry_40_future_productivity_ growth_manufacturing_industries.

Berend T. Iván [2013]: Europe in Crisis. Bolt from the Blue? Routledge, New York, London. 180 o.

Bergeaud, A.-Cette, G.-Lecat, R. [2014]: Productivity Trends from 1890 to 2012 in Advanced Countries. Banque de France, Document de Travail, No. 475. https://doi.org/10.2139/ ssrn.2414367.

Bergeaud, A.-Cette, G.-Lecat, R. [2015]: GDP Per Capita in Advanced Countries over the 20th Century. 2015. április, Banque de France, Document de Travail, No. 549. https://doi. org/10.2139/ssrn.2602267.

Bessen, J. E. [2016]: How Computer Automation Affects Occupations: Technology, Jobs, and Skills. Boston University School of Law, Law and Economics Research Paper, No. 15-49. https://doi.org/10.2139/ssrn.2690435.

Blanchard, O. [2016]: Slow Growth is a Fact of Life in the Post-Crisis World. Financial Times, április 13. https://www.ft.com/content/c84e2bfe-0171-11e6-99cb-83242733f755? mhq5j=e2.

BLIX, M. [2015]: The Economy and Digitalization-Opportunities and Challenges. Confederation of Swedish Enterprise, http://www.martenblix.com/uploads/6/2/7/2/62723607/blix_ digitalization_report_20160206.pdf.

BőgEL György [2015]: Will Software Eat Your Food? Digital Transformation of Agriculture. CEU Working Paper, No. 6.

Byrne, D. M.-Corrado, C. [2017]: ICT Prices and ICT Services: What Do They Tell us about Productivity and Technology? Finance and Economics Discussion Series, 2017-015. Washington: Board of Governors of the Federal Reserve System, Washington, D. C. https://doi. org/10.17016/feds.2017.015.

Byrne, D. M.-Fernald, J. G.-Reinsdorf, M. B. [2016]: Does the United States Have a Productivity Slowdown or a Measurement Problem? Finance and Economics Discussion Series, 2016-017. Board of Governors of the Federal Reserve System. Washington, D. C. https:// doi.org/10.17016/feds.2016.017. 
Candelon, B.-Amadou, N. R. Sy [2015]: How Did Markets React to Stress Tests? IMF Working Paper, Vol. 15. No. 75. https://doi.org/10.5089/9781484315378.001.

Cette, G.-Lopez, J. [2012]: ICT Demand Behaviour: An International Comparison. Economics of Innovation and New Technology, Vol. 21. No. 4. 397-410. o. https://doi.org/10. 1080/10438599.2011.595921.

Cette, G.-Clerk, C.-Bresson, L. [2015]: Contribution of ICT Diffusion to Labour Productivity Growth: The United States, Canada, the Eurozone, and the United Kingdom, 19702013. International Productivity Monitor, Vol. 28. 81-88. o.

Cette, G.-Lopez, J.-Mairesse, J. [2016]: Labour Market Regulations and Capital Intensity. NBER Working Papers, No. 22603. https://doi.org/10.3386/w22603.

Chong, E. Y. L.-Mody, A.-Sandoval, F. V. [2017]: Finance and Growth: The Direction of Causality. VoxEU.org, január 17. http://voxeu.org/article/finance-and-growth-directioncausality.

Corrado, C.-Haskel, J.-Jona-Lasinio, C. [2016]: Intangibles, ICT and industry productivity growth: Evidence from the EU. Megjelent: Jorgenson, D.-Fukao, K.-Timmer, M. (szerk.): The World Economy: Growth or Stagnation? Cambridge University Press, Cambridge, 281-318. o. https://doi.org/10.1017/9781316534502.009.

Cowen, T. [2011]: The Great Stagnation: How America Ate All The Low-Hanging Fruit of Modern History, Got Sick, and Will (Eventually) Feel Better. Penguin-Dutton, New York, 128 o.

EC [2013]: Third Alert Mechanism Report on macroeconomic imbalances in EU Member States. Brüsszel, http://europa.eu/rapid/press-release_MEMO-13-970_en.htm.

EC [2014]: Fourth Alert Mechanism Report on macroeconomic imbalances in EU Member States. Brüsszel, november, http://europa.eu/rapid/press-release_MEMO-14-2231_en.htm. EC [2015]: Alert Mechanism Report 2016. European Commission COM(2015) 691 final. Brüsszel, november 26. http://ec.europa.eu/europe2020/pdf/2016/ags2016_alert_ mechanism_report.pdf.

EC [2016a]: The EU Data Protection Reform and Big Data: Factsheet.European Commission, http:// ec.europa.eu/justice/data-protection/files/data-protection-big-data_factsheet_web_en.pdf.

EC [2016b]: Education and Training Monitor 2016. http://ec.europa.eu/education/sites/ education/files/monitor2016_en.pdf.

Einav, L.-Levin, J. D. [2014]: The Data Revolution and Economic Analysis. In: Lerner, J.Stern, S. (szerk.): Innovation Policy and the Economy. NBER Book Series Innovation Policy and the Economy, 14. kiadás, 1-24. o.

EP [2016]: Industry 4.0 Analytical Study. European Parliament, Directorate General for Internal Policies. Policy Department A: Economic and Scientific Policy. IP/A/ ITRE/2015-02, European Parliament, http://www.europarl.europa.eu/RegData/etudes/ STUD/2016/570007/IPOL_STU(2016)570007_EN.pdf.

ESBR [2016]: Shedding Lights on Dark Markets. First Insights from the New EU-wide OTC Derivatives Dataset. European Systemic Risk Board, Occasional Paper Series, No. 11. https:// www.esrb.europa.eu/pub/pdf/occasional/20160922_occasional_paper_11.en.pdf.

Eurostat [2016]: ICT specialists - statistics on hard-to-fill vacancies in enterprises. http:// ec.europa.eu/eurostat/statistics-explained/index.php/ICT_specialists_-_statistics_on_ hard-to-fill_vacancies_in_enterprises.

Foray, D. [2014]: From Smart Specialisation to Smart Specialisation Policy. European Journal of Innovation Management, Vol. 17. No. 4. 492-507. o. https://doi.org/10.1108/ejim09-2014-0096. 
Foray, D.-Mowery, D. D.-Nelson, R. R. (szerk.) [2012]: The Need for a New Generation of Policy Instruments to Respond to the Grand Challenges. Research Policy, Vol. 41. No. 10. 1697-1792. o.

GLushko, R. J. [2008]: Designing a Service Science Discipline with Discipline. IBM Systems Journal, Vol. 47. No. 1. 15-27. o. https://doi.org/10.1147/sj.471.0015.

Gordon, R. J. [2012]: Is US Economic Growth Over? Faltering Innovation Confronts the Six Headwinds. NBER Working Paper, No. 18315. https://doi.org/10.3386/w18315.

Halmai PÉter [2014]: Krízis és növekedés az Európai Unióban. Európai modell, strukturális reformok. Akadémiai Kiadó, Budapest, 370 o.

Hausmann, R.-Rodrik, D. [2006]: Doomed to Choose: Industrial Policy as Predicament. Kézirat, http://drodrik.scholar.harvard.edu/files/dani-rodrik/files/doomed-to-choose.pdf.

Hogan, O.-Holdgate L.-Jayasuriya, R. [2016]: The Value of Big Data and the Internet of Things to the UK Economy. Report for SAS. Centre for Economics and Business Research CEBR, London, http://www.sas.com/content/dam/SAS/en_gb/doc/analystreport/cebrvalue-of-big-data.pdf.

Hoon, H. T.-Phelps, E. S. [2006]: Effects of Technological Improvement in the ICTProducing Sector on Business Activity. Columbia University Academic Commons, http:// hdl.handle.net/10022/AC:P:446.

IMF [2015]: World Economic Outlook, April 2015: Uneven Growth - Short and Long-Term Factors. IMF, Washington, D. C.

IMF [2016]: World Economic Outlook Update. Uncertainty in the Aftermath of the U.K. Referendum. IMF, Washington, D. C.

InNODRIVE [2011]: Intangible Capital and Innovation: Drivers of Growth in the EU. Policy Brief, http://www.innodrive.org/attachments/File/INNODRIVE_policy\%20brief_ february_2011_02_20_final.pdf.

Isson, J. P.-HARriott, J. S. [2016]: People Analytics in the Era of Big Data: Changing the Way You Attract, Acquire, Develop, and Retain Talent. Wiley Publishing.

Kahneman, D. [1999]: Objective Happiness. Megjelent: Kahnenam, D.-Diener, E.-Schwarz, N. (szerk.): Well-being: The Foundations of Hedonic Psychology. Russell Sage, 3-25. o.

Kahnenam, D.-Diener, E.-Schwarz, N. (szerk.) [2003]: Well-Being: The Foundations of Hedonic Psychology. Russell Sage Foundation, 605 o.

Ketels, C.-Protsiv, S. [2014]: European Cluster Panorama 2014. European Cluster Observatory, European Commission, http://eco2.inno-projects.net/2014-10-15-cluster-panorama-d1.4a.pdf.

KNight, F. H. [1921]: Risk, Uncertainty and Profit. Harper, New York.

Kortum, S.-Pillai, U. [2015]: Comment. Master, National Bureau of Economic Research, 52-59. o.

KovÁcs Olivér [2012]: Policies Supporting Innovation in Public Service Provision. INNOGrips Policy Brief. European Commission, DG Enterprise and Industry, http://oliverkovacs. com/policies-supporting-innovation-in-public-service-provision.

Kovács Olivér [2015a]: Stabilitás és dinamizmus. Az innovatív fiskális politika alapjai. Alinea Kiadó, Budapest.

Kovács Olivér [2015b]: A magyar différance. Köz-Gazdaság, 10. évf. 4. sz. 145-166. o.

KovÁcs Olivér [2016]: Talent-competitiveness of Hungary. Decline without „Fleurs du Mal”. Society and Economy, Vol. 38. No. 4. 537-558. o. https://doi.org/10.1556/204.2016.38.4.6.

Kretschmer, T. [2012]: Information and Communication Technologies and Productivity Growth: A Survey of the Literature. OECD Publishing, OECD Digital Economy Papers, No. 95. https://doi.org/10.1787/5k9bh3jllgs7-en. 
Krugman, P. [1997]: The Age of Diminished Expectations. Third Edition: U.S. Economic Policy in the 1990s. MIT Press, Cambridge, MA.

Mauro, P.-Zilinsky, J. [2016]: Reducing Government Debt Ratios in an Era of Low Growth. Policy Brief, Peterson Institute for International Economics, július, https://piie.com/system/ files/documents/pb16-10.pdf.

McQuinn, K.-Whelan, K. [2015]: Europe's Long-Term Growth Prospects: With and Without Structural Reforms. Economic and Social Research Institute, ESRI Papers, No. WP501.

MGI [2013]: Disruptive Technologies: Advances that will Transform Life, Business, and the Global Economy. http://www.mckinsey.com/business-functions/digital-mckinsey/ourinsights/disruptive-technologies.

MONOSTORI LÁszLó [2017]: A számítógépes szerszámgépvezérlésektől a kiberfizikai termelési rendszerekig. Székfoglaló előadás. Magyar Tudományos Akadémia, Budapest, január 20.

Muller, P.-Devnani, S.-Julius, J.-Gagliardi, D.-Marzocchi, C. [2016]: Annual Report on European SMEs 2015/2016. EASME /COSME/2015/012. https:/ec.europa.eu/jrc/sites/ jrcsh/files/annual_report_-_eu_smes_2015-16.pdf.

Nolan, B.-Roser, M.-Thewissen, S. [2016]: GDP per Capita versus Median Household Income: What Gives Rise to Divergence Over Time? Oxford, INET Working Paper Series, 3 .

OECD [2013]: Supporting Investment in Knowledge Capital, Growth and Innovation. OECD, Párizs, https://doi.org/10.1787/9789264193307-en.

OECD [2015a]: The Future of Productivity. OECD, Párizs, https://doi.org/10.1787/ 9789264248533-en.

OECD [2015b]: Making Inclusive Growth Happen. All On Board. OECD, Párizs, https://doi. org/10.1787/9789264218512-en.

OECD [2016]: Enabling the Next Production Revolution: The Future of Manufacturing and Services. Interim Report. Meeting of the OECD Council at Ministerial Level. OECD, Párizs, június 1-2. https://www.oecd.org/mcm/documents/Enabling-the-next-productionrevolution-the-future-of-manufacturing-and-services-interim-report.pdf.

Perotti, R. [1996]: Growth, Income Distribution, and Democracy: What the Data Say. Journal of Economic Growth, Vol. 1. No. 2. 149-187. o. https://doi.org/10.1007/BF00138861.

Phelps, E. S. [2013]: Mass Flourishing: How Grassroots Innovation Created Jobs, Challenge, and Change. Princeton University Press, Princeton, 392 o.

Pilat, D.-Nolan, A. [2016]: Benefiting from the Next Production Revolution. Megjelent: OECD Insights/Debate the Issues: New Approaches to Economic Challenges. OECD Publishing, Párizs, 117-122. o. https://doi.org/10.1787/9789264264687-22-en.

Procorre [2016]: Data Scientist Roles Surge in First Half of 2016. Procorre, http://blog. procorre.com/data-scientist-roles-surge-in-first-half-of-2016.

Robles, J. M.-De Marco, S.-Antino, M. [2013]: Activating Activists. The Links between Political Participation and Digital Political Participation. Information, Communication and Society, Vol. 16. No. 6. 856-877. o. https://doi.org/10.1080/1369118x.2012.738238.

Robles, J. M.-De Marco, S.-Antino, M. [2016]: Development and Validation of the Digital Political Participation Inventory: Surveys and Big Data. ECPR General Conference, Prága, szeptember 7-10.

Ross, A. [2016]: The Industries of the Future. Simon and Schuster, 320 o.

Schwa B, K. [2016]: The Fourth Industrial Revolution. World Economic Forum, január 11. Teulings, C.-BAldwin, R. (szerk.) [2014]: Secular Stagnation: Facts, Causes and Cures. A VoxEU.org Book. CEPR Press. 
Turner, A. [2015]: Between Debt and the Devil: Money, Credit, and Fixing Global Finance. Princeton University Press, Princeton, 320 o. https://doi.org/10.1515/9781400873326.

UNRISD [2016]: Policy Innovations for Transformative Change. UNRISD Flagship Report. Genf, http://www.unrisd.org/UNRISD/website/projects.nsf/(httpProjects)/AC3E80757E7 BD4E9C1257F310050863D?OpenDocument.

Van Ark, B.-Erumban, A.-Corrado, C.-Levanon, G. [2016]: Navigating the New Digital Economy: Driving Digital Growth and Productivity from Installation to Deployment. The Conference Board, https://www.conference-board.org/publications/publicationdetail.cfm? publicationid $=7215 \&$ centerId $=6$.

Van Ark, B.-O’Mahony, M.-Timmer, M. [2008]: The Productivity Gap between Europe and the United States: Trends and Causes. Journal of Economic Perspectives, Vol. 22. No. 1. sz. 25-44. o. https://doi.org/10.1257/jep.22.1.25.

Van Welsum, D.-Overmeer, W.-van Ark, B. [2012]: Unlocking the ICT Growth Potential in Europe: Enabling People and Businesses. Using Scenarios to Build a New Narrative for the Role of ICT in Growth in Europe. European Commission, DG Communications Networks, Content \& Technology.

Walz, R. [2015]: Green Industrial Policy in Europe. Which Industrial Policy Does Europe Need? Forum, Intereconomics, Vol. 50. No. 3. 145-152. o. https://doi.org/10.1007/s10272015-0535-1. 